Portland State University

PDXScholar

\title{
Frequency of Limited English Proficient (LEP) Patient Visits and Language Resources: an Assessment of Rural Oregon's Health Centers and Working with LEP Communities
}

Gabriel I. Lehrburger

Portland State University

Follow this and additional works at: https://pdxscholar.library.pdx.edu/honorstheses

Part of the Communication Commons, and the Health Services Administration Commons Let us know how access to this document benefits you.

\section{Recommended Citation}

Lehrburger, Gabriel I., "Frequency of Limited English Proficient (LEP) Patient Visits and Language Resources: an Assessment of Rural Oregon's Health Centers and Working with LEP Communities" (2020). University Honors Theses. Paper 903.

https://doi.org/10.15760/honors.925

This Thesis is brought to you for free and open access. It has been accepted for inclusion in University Honors Theses by an authorized administrator of PDXScholar. Please contact us if we can make this document more accessible: pdxscholar@pdx.edu. 
Frequency of Limited English Proficient (LEP) Patient Visits and Language

Resources: An Assessment of Rural Oregon's Health Centers and Working with LEP

Communities

By

Gabriel I Lehrburger

An undergraduate honors thesis submitted in partial fulfillment of the requirements for the degree of

\author{
Bachelor of Arts \\ in \\ University Honors \\ and \\ Spanish and General Science
}

Thesis Advisor

Dr. Claire Wheeler

Portland State University

June 12, 2020 


\begin{abstract}
Persons with limited English proficiency (LEP) can face barriers when seeking health care. Rural communities often have reduced access to some health resources. However, little is known about how rural communities meet the language needs of their LEP populations. A cross-sectional survey and interview were designed and sent to managerial staff in rural health centers around the state of Oregon. During the months of January - March 2020, survey and interview data were collected to assess the relationship between frequency of LEP patient visits and available language resources in rural Oregon. The study also investigated staff perceptions when working with patients with LEP. Data responses came from centers in mainly northern, northeastern, and coastal regions of the state. Data suggested that clinics that see higher numbers of patients with LEP have more onsite bilingual staff and interpreter resources available than health centers with less regular LEP patient visits. Clinics preferred the use of bilingual staff during visits, rather than relying on remote interpreting services, and preferred onsite interpretation, instead of remote interpretation. Further, clinics perceived that the population of LEP patients was growing across the state. One promising method for meeting demands of language resources is implementing certification courses for bilingual care staff and community members. State-subsidized certification courses could increase the availability of certified bilingual health workers trained in medical interpretation, as well as provide opportunities for bilingual community members to become trained as certified medical interpreters.
\end{abstract}

Keywords: LEP, rural, health care, health care interpreters, bilingual staff 


\section{Frequency of Limited English Proficient (LEP) Patient Visits and Language}

\section{Resources: An Assessment of Rural Oregon's Health Centers and Working with LEP \\ Communities}

Limited English proficiency (LEP) is a term used to describe one's own perception of their ability to speak English fluently; U.S. Census Bureau statistics show 25 million persons in the United States over the age of five who self-reported speaking English less than "very well” (Lep.gov, 2018; U.S. Census Bureau, 2015). Latinxs make up a disproportionate 63\% of those in the U.S. with LEP: an estimated 15.8 million individuals (Zong \& Batalova, 2015).

People with LEP can face daily challenges; however, one significant threat to wellbeing is access to health care. Research has identified that language barriers in a health care setting can result in miscommunications between patients and health workers, which significantly increases chances of serious medical events (Cohen et al., 2005; Kim et al., 2011). Language barriers have been correlated with failure to adhere to medical instructions or return to follow-up visits, as well as reduced access to preventative medicine such as cancer screenings and annual PCP visits (DuBard \& Gizlice, 2008; Isasi et al., 2016). Uninsured rates are higher among Spanish-speaking Latinxs, and Latinxs remain the highest uninsured population in the United States (DuBard \& Gizlice, 2008; Kaiser Family Foundation, 2020).

Professional language interpreters have been identified as an effective method for reducing language and culture barriers in health care settings (Wasserman et al., 2014). The use of professionally trained interpreters increases patient satisfaction, decreases miscommunication and improves access to quality health care for limited English patients (Tschurtz et al., 2011). Title VI of the Civil Rights Act of 1964 states that any person that 
receives health or human services from an organization that is federally funded has the legal right to receive care, regardless of race, ethnicity, skin color, or national origin (U.S. Department of Health and Human Services Office of Civil Rights, 2019). Language falls into the category of national origin and failing to provide meaningful access to individuals on the basis of language barriers therefore violates Title VI (LEP.gov, 2018). The Office of Civil Rights has issued policy guidelines to help federal services comply to Title VI, stating that LEP persons must be notified of the availability of free language assistance and that these services must be offered at the expense of the organization, not the LEP person (Tschurtz et al., 2011). LEP patients receiving federal financial assistance such as Medicare or Medicaid have the right to a professionally trained medical interpreter without having to pay for these services (Jacobs et al., 2018).

Another meaningful method for providing care to patients with language barriers is language-concordant providers and staff. Research has identified a positive correlation between physician language ability/cultural competence and better self- reported processes of interpersonal care with Spanish-speaking patients (Fernandez et al., 2004). Language concordant Spanish-speaking physicians and patients has been correlated with improved health outcomes for patients with diabetes, pain management, cancer treatments and overall satisfaction with care and communication (Diamond et al., 2019; Parker et al., 2017).

\section{Challenges in Rural Health}

Compared to urban areas, there are remarkable disparities in access to quality care for persons living in rural regions of the United States (Douthit et al., 2015). Patients of rural regions of the U.S. simultaneously have higher levels of chronic disease, poorer health outcomes, and poorer access to digital healthcare, as well as suffer from higher rates of obesity, tobacco use and substance abuse, and lower rates of preventative medicine including cancer screenings 
and annual checkups, compared to persons living in urban areas (Douthit et al., 2015). As an enterprise, rural medicine faces barriers to providing quality care to its residents, including limited access to technology and medical personnel, inadequate facilities, and insufficient funding (Klugman \& Dalinis, 2008). As a result, these barriers in health care significantly impact the quality of life and health outcomes of rural patients (Douthit et al., 2015). Much of the research that has investigated LEP patients, interpreter use, and language concordance has taken place in emergency departments and urban hospital settings, however, very limited research has been done in primary care clinics. Further, even less is known about primary care and LEP patients of rural parts of the United States.

\section{Rural Oregon and LEPS}

Oregon is an agricultural state, where much of the population lives in rural regions. As of now, an estimated $36 \%$ of Oregonians find themselves living in rural parts of the state, far above the national average of $20 \%(\mathrm{ORH}, 2019)$. The Oregon Office of Rural Health (ORH) has defined rural "as any geographic areas in Oregon ten or more miles from the centroid of a population center of 40,000 people or more," (p. 4) and frontier "as any county with six or fewer people per square mile.” (p. 4) (ORH, 2019). Latinxs are the largest ethnic minority group in Oregon and are growing at a rate that is faster that the national average; estimates suggest that $12 \%$ of Oregon residents are of Latinx descent, which represents a $70 \%$ growth since the year 2000 (Ruffenach et al., 2016). Census statistics showed that $6.2 \%$ of Oregon's 3.6 million residents self-reported with LEP and 63\% of those were Spanish speaking, a total of 143,041 individuals (LEP.gov, 2020; U.S. Census Bureau, 2015). No research has currently identified the exact population of rural Oregon residents that is limited in English proficiency. 
Due to the rapidly increasing Latinx population in the state and the high proportion of rural residents, Oregon sits as a good model for assessing how primary care clinics in rural settings address the needs of patients with limited English fluency. There is limited information currently available that has explored the method's that Oregon's rural clinics follow in order to provide accessibility to limited English proficient patients in their area. The purpose of this study is to understand how primary health care facilities located in rural parts of the state work to provide care for patients with LEP. Using information gathered from self-reported surveys and interviews of managerial staff in rural health facilities located in northern, northeastern and coastal regions of Oregon during the months of January - March 2020, this investigation explores how the prioritization of bilingual providers/staff, interpretation agencies and other language resources are affected by the variance in frequency that clinics report working with LEP patients. The focus of this research project was language resources available in Spanish, however this investigation was inclusive to all non-English language resources that clinics utilize. With an understanding for how primary care clinics have best prepared to serve patients of limited English fluency under variable visit frequencies, successful procedures and practices may be identified that can be followed by others in the future. As the population of Oregon continues to grow and diversify, a greater understanding of these methods may provide necessary support to clinical staff and, ultimately, to the people of Oregon. 


\section{Methodology}

\section{IRB Approval}

IRB approval was not required for this research. The population for this study included clinics located around the state. Although personnel of participating clinics completed surveys and participated in interviews, the information collected during these interactions was not personal and instead pertained only to the clinics. Professor William York, Ph.D. of the Portland State University Honors College was in accordance and agreed that IRB approval was not necessary.

\section{Participating Clinics}

The population for this study included medical facilities that met two criteria: 1) clinics and hospitals must be located in areas of the state that are considered as either 'rural' or 'frontier', according to the definitions described by the ORH, and 2) medical facilities must accept patients that receive government assisted medical insurance (Medicaid and/or Medicare). Medical facilities that were considered for this research included Critical Access Hospitals (CAHs), Rural Health Clinics (RHCs) and Federally Qualified Health Centers (FQHCs) that were located in rural regions of Oregon. Using the contact information for Oregon's CAHs and RHCs that is available on the Oregon Office of Rural Health website https://www.ohsu.edu/oregon-office-of-rural-health, information for all RHCs and CAHs was collected. Information regarding FQHCs was collected from the Oregon Primary Care Association (OPCA) at https://www.orpca.org/chc/find-a-chc.

In total, $25 \mathrm{CAHs}, 102 \mathrm{RHCs}$, and $52 \mathrm{FQHCs}$ were considered for this study. Of the

36 counties in Oregon, no health facilities of interest were located in the counties of Multnomah or Yamhill. 


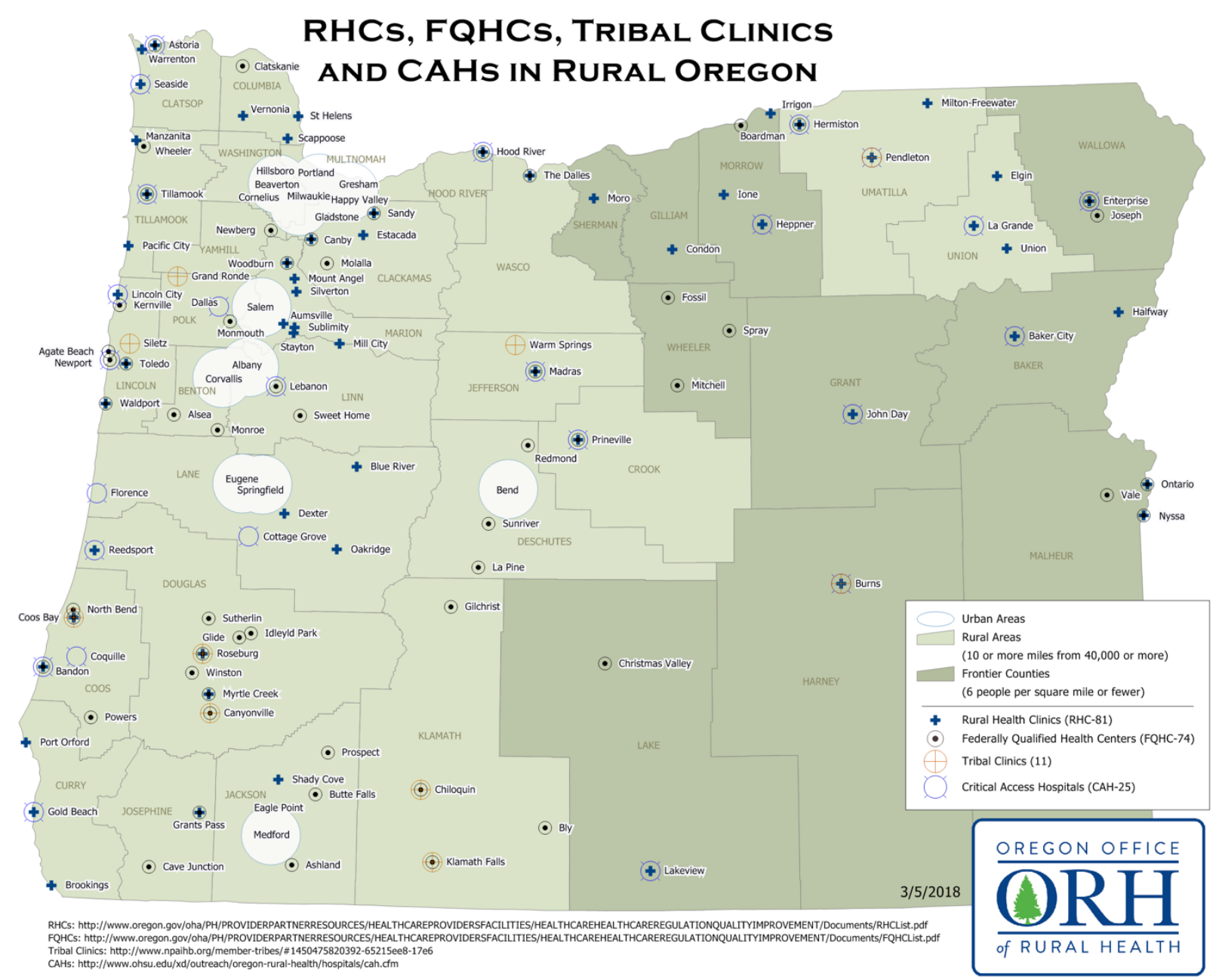

Figure 1: Map of Oregon Certified Rural Health Clinics (RHCs), Federally Qualified Health Centers (FQHCs), Tribal Clinics, and Critical Access Hospitals (CAHs) in rural Oregon. Map made available to the public by the ORH at https://www.ohsu.edu/oregon-office-of-ruralhealth/facilities-services

\section{Surveys}

A cross-sectional survey [Appendix A] was designed in Google Forms that assessed selfreported frequency of LEP patient visits as well as the language resources that were available to LEP patients. Qualitative measures assessed perceptions that managers felt when clinical staff worked with LEP patients, as well as assessed perceptions related to the use of $3^{\text {rd }}$ party 
interpretation agencies. The survey could be completed by following an attached hyperlink. The survey remained open during the months of January - March 2020

Surveys sent via email - In coordination with the ORH Field Services Program Manager, Rondyann Gerst, surveys were sent via email to 139 managerial staff of RHCs and CAHs on January 29, 2020. Survey recipients included clinic managers, administrators, supervisors, project coordinators, directors and executives. The contact information of these participants was conserved by the ORH; thus, the survey was sent to Ms. Gerst, who then forwarded it on to participants.

Surveys sent via facsimile - Between February $1^{\text {st }}$ and March $10^{\text {th }}$ of 2020 , CAHs, RHCs, and FQHCs that had not responded to the Google Forms survey were contacted via phone during normal business hours. When connected with a receptionist, the parameters of the investigation were explained, and staff were asked if a manager was available for further questions. If managers were unavailable, a voice message was left on the manager's answering machine and surveys addressed to the managerial staff were sent to health facilities using facsimile. If managers were available, the parameters of the study were explained again, and managers were asked if they would participate by completing a survey that could be faxed or emailed, or by participating in a phone interview of approximately 10 minutes. Due to the rising spread of the pandemic outbreak of the novel coronavirus, COVID-19, attempts to contact clinics via phone ceased on March 10, 2020 in order to reduce nonemergency calls to clinics and hospitals during the period of state of emergency.

\section{Availability of Spanish-speaking representatives}

Facilities that participated in completing the survey were contacted and thanked for their participation. Upon making this call, the option of whether or not clinics had the availability 
to speak with a representative in Spanish (by pressing a number on the keypad) was recorded for each facility.

\section{Interviews}

The survey included a question that asked if clinical staff would be willing to participate in a follow-up interview, and clinic personnel could leave contact information if interested. Personnel willing to participate in interviews were contacted. Interviews assessed the completed survey responses and assessed frequency of LEP patient visits, uses of language resources within the clinics and perceived need of additional language resources for patients. Interviews were recorded with consent of the managerial staff. Data were obtained during the months of February, and March of 2020.

Interview questions were divided into five categories and addressed:

- Demographics

- Proportion of patients with LEP

- Frequency of LEP patient visits

- Languages spoken by LEP patients

- Reliance on outside assistance for language resources

- Hospital/clinic

$\circ$ On-hand language resources

- Onsite/staffed interpreters, bilingual staff, bilingual providers

- Certification of said staff

- Use of ad hoc interpreters

- Interpretation Services

$\circ$ Use of $3^{\text {rd }}$ party interpretation/translation agencies.

- onsite vs. remote interpreting

- telephonic vs. video

○ Preferences of staff/providers

- onsite or remote interpreting

- phone or video interpreting (if applicable).

- satisfaction of with these services 
- does manager/staff believe that quality of service had changed in recent years?

○ Costs

- certification process

- contract with agency

- CCO involvement

- Onsite

- Physical resources on-hand

- Brochures, posters etc.

- signs in various languages

- advertise interpreter availability

- Needs

- Perception of success in providing quality care to LEP patients

- lack of sufficient services available

- or, if needs were met

- Interpreters addressed in board meetings

- Perceived increase, decrease, or no change in number of LEP patients in recent years.

- Would community benefit from having more qualified interpreters available

\section{Analysis}

Framework of analysis - This cross-sectional study used a survey to quantitatively assess the relationship between frequency of LEP patient visits and available resources for patients of limited English. Survey data identified the frequency of how often facilities self-reported LEP patient appointments, as well as determined various resources that centers had for working with patients of limited English. Data were compiled in a Resource Table [Table 2] that was primarily assessed using descriptive analysis.

This study also investigated the preferences that health centers had when working with interpreters, bilingual staff and patients when there is a language barrier. Survey and interview data qualitatively explored preferences for serving patients of limited English. Interviews were not designed to function as case studies, but rather functioned as a means of understanding patterns that appeared in survey data. Together, both survey and interview data 
were used to assess the relationship that exists between frequency of LEP appointments and availability of resources, as well as draw conclusions about serving LEP patients in rural settings.

Survey data - Using quantitative survey data, a comparative chart [Table 2] displayed survey responses from all participants and compared frequency of LEP patient visits with available language resources. Data in Table 2 were analyzed using descriptive statistics. Data were summarized into Table 3. When comparing frequency, data were grouped either by each frequency individually, or 'rarely' and 'monthly' were grouped for lower frequency data and 'weekly' and 'daily' were grouped as high frequency data. Qualitative survey data were collected into Table 4. Data examined healthcare center' perceptions for working with $3^{\text {rd }}$ party interpretation agencies as well as staff preferences for practices of best care during LEP patient appointments. Significance was assessed using Chi square and ANOVA single variance tests with 95\% CI.

Interview data - Interviews were transcribed with the assistance of the transcription software Happy Scribe. Interviews were then reviewed and edited manually. Coding was done with the assistance of the coding software, Taguette. Using coding frameworks defined by Saldaña in the second edition of his work, The Coding Manual for Qualitative Researchers (2013), a coding scheme was designed. Analysis began with Descriptive Coding (Saldaña, 2013), and data were categorized into groups for future analysis. Second cycle coding comprised of In Vivo Coding (Saldaña, 2013), whereby direct quotes from interviewees were organized into the previously defined categories. Reoccurring themes from the In Vivo quotes were written as discussion points. Table 5 displays emerging themes and discussion points. Coding data are available in Appendix B. 


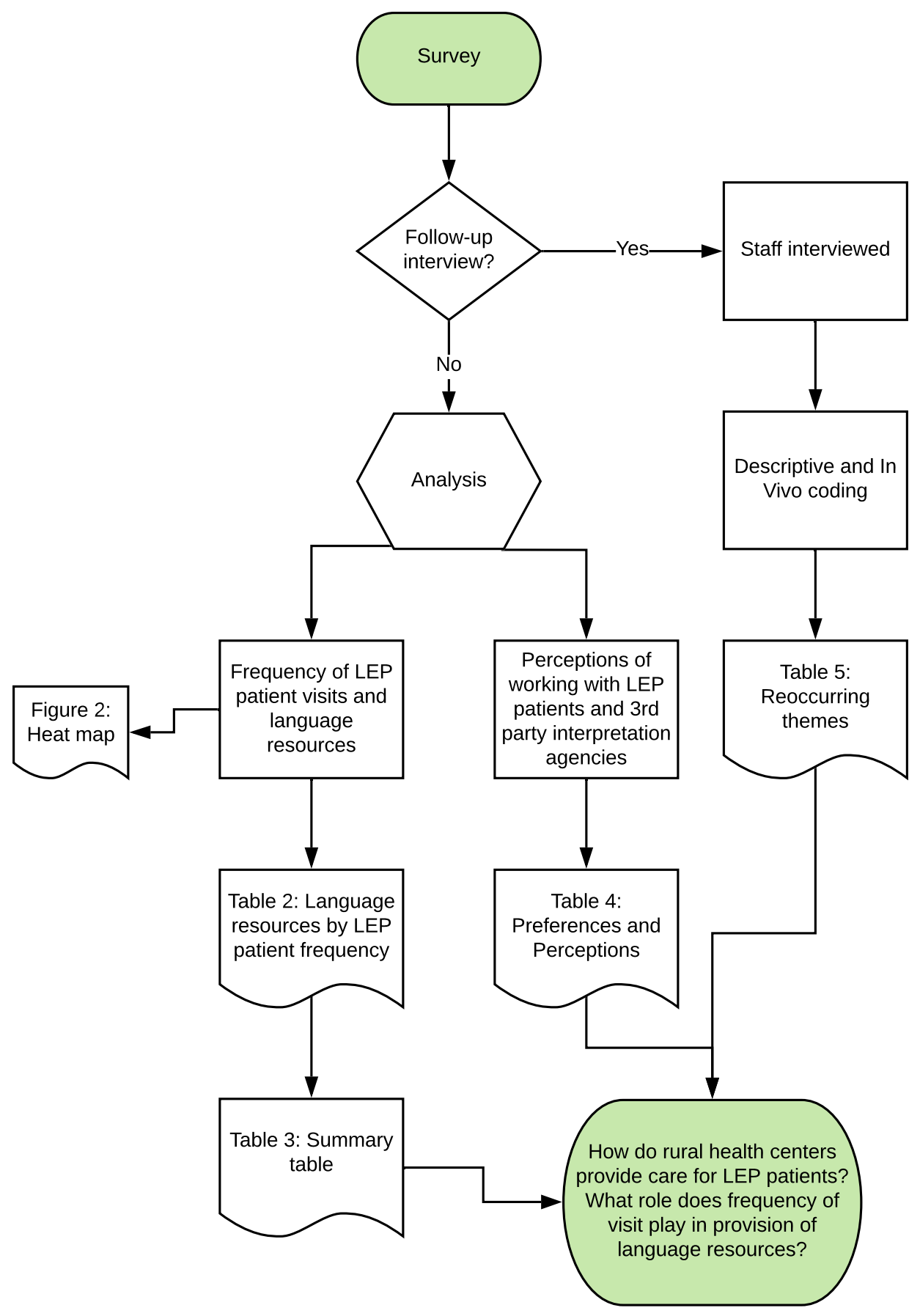

Figure 2: Flow chart of analysis process. 


\section{Results}

Of the 139 surveys sent on January $29^{\text {th }}, 32(23 \%)$ respondents completed and returned the survey. Phone calls were made to 47 additional facilities in the coming weeks. Surveys were faxed to 15 locations and one response was returned. A total of 33 surveys were collected.

Of the information gathered, some managers represented multiple clinic locations. Further, in some participating facilities, multiple managers and personnel completed and returned surveys, resulting in multiple data points collected from the same facilities (North Bend Medical Center $n=4$, Orchid Health clinics $n=2)$. Two respondents $(n=2)$ did not specify clinic names, but provided city of clinic location. No survey data was omitted from analysis.

Six participants (18\%) agreed to follow-up interviews. When contacting personnel to participate in the study, one manager opted for a phone interview but did not complete a survey. In total, the combination of the 33 surveys and seven interviews accumulated information from 33 individual health facilities in the state, located in 18 of the 34 counties of interest. Data were collected from north, northeast and costal rural regions of the state. Respondents included 2 CAHs, 28 RHCs and 3 FQHCs. The number of participating facilities located in each Oregon county ranged from $0-4$, with a median of 1 response per county. 


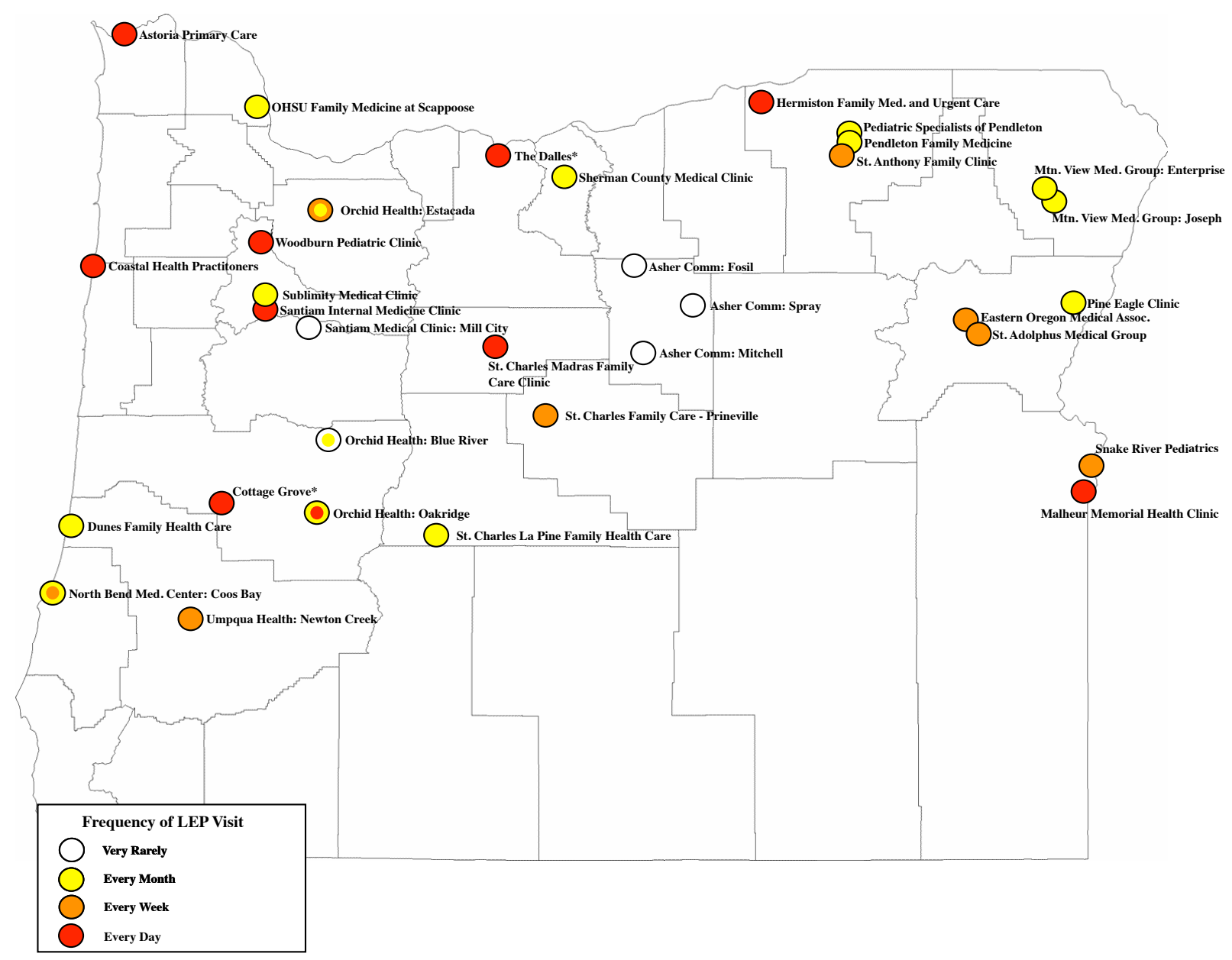

Figure 3: Heat map graphically displays the locations and counties of participating facilities. Color-coded points identify location, as well as represent healthcare facility's frequency of working with LEP patients. Some points contain multiple colors; these represent the varying responses to frequency gathered from surveys. Locations marked with asterisks $(*)$ indicate that the responding facilities did not specify name, but provided only a city of location.

\section{Languages spoken by LEP patients}

Survey respondents identified six principal languages spoken by LEP patients. The primary language spoken was Spanish; $91 \%$ of participating facilities indicating that they had patients that primarily spoke this language. $42 \%$ of participating clinics worked with patients that spoke American Sign Language (ASL), whereas 39\% of respondents indicated that they had patients that primarily spoke Chinese. Other languages identified included Vietnamese, 
Russian and Arabic, with a respective $15 \%, 12 \%$ and $9 \%$ of facilities indicating that they had a patient body that primarily spoke these languages. Five respondents $(15 \%)$ indicated that their patient population was primarily English-speaking.

Table 1: Languages spoken by LEP patients in participating health facilities of rural Oregon.

\begin{tabular}{|l|l|l|}
\hline Language(s) Spoken by LEP & \multicolumn{2}{|l}{} \\
Patients & Facilities & $\%$ \\
\hline Spanish & $30 / 33$ & 91 \\
American Sign Language & $14 / 33$ & 42 \\
Chinese & $13 / 33$ & 39 \\
Vietnamese & $5 / 33$ & 15 \\
Russian & $4 / 33$ & 12 \\
Arabic & $3 / 33$ & 09 \\
Other & $3 / 33$ & 09 \\
None (primarily English-speaking) & $5 / 33$ & 15 \\
\hline
\end{tabular}

\section{Frequency of LEP visits}

Data collected regarding the frequency of LEP patient visits identified that $31 \%$ of respondents reported working with patients of limited English every day. 18\% of respondents reported working with LEP patient visits every week. 38\% of participants identified that their healthcare center worked with limited English patients each month, and 13\% of respondents indicated that their establishment works with LEP patients fewer than every month. 


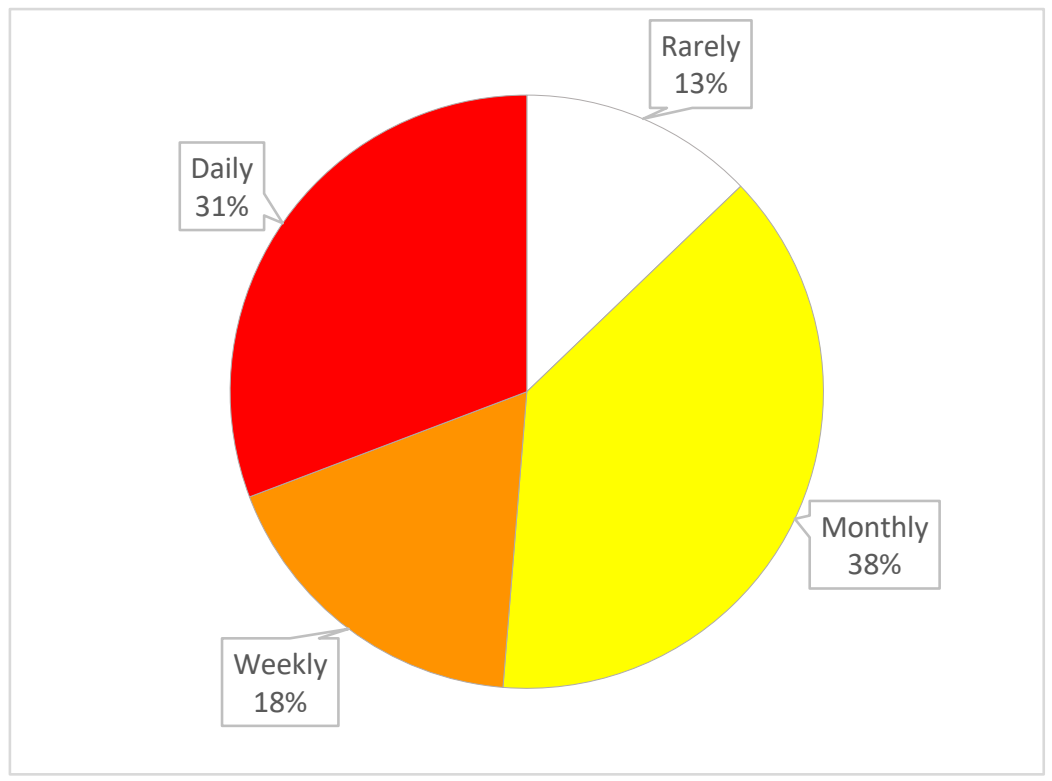

Figure 4: Frequency of LEP visits in participating healthcare centers.

\section{Frequency of LEP visits and Resources for when there are language barriers}

Bilingual staff and staffed certified interpreters were considered as in-house language resources. Healthcare centers that indicated weekly LEP patient visits had the highest proportion of in-house resources, with $86 \%$ of clinics that serve patients of limited English on a weekly basis indicating either on-hand staff that were bilingual or employees that were certified interpreters, or both. Nearly all health facilities marked the use of $3^{\text {rd }}$ party interpretation/translation agencies for assisting patients. $94 \%$ of participants said their clinic had resources available from outside interpretation companies. Most of these services were provided remotely, by either phone or video, and very few participants (11\%) identified ever having onsite interpreters for their patients. About half $(46 \%)$ of respondents indicated their clinic may use family or friends for assisting with interpretation (ad hoc) with 7/12 (58\%) of the high frequency 'daily' respondents indicating the use of ad hoc interpreters. One section on the survey asked about onsite physical resources, such as brochures, posters, signs, etc. No respondents $(0 \%)$ completed this portion of the survey, and the section was removed from 
analysis. When calling clinics, many had voice recordings that provided clinic information as well as gave various number button options for speaking with specific persons and clinic departments. However, very few (11\%) had an option available for speaking with a representative in Spanish.

Rural clinics rely significantly more on outside interpreter resources than inside resources $(\mathrm{p}<0.001)$. Clinics reported heavy use of ad hoc interpreters in 'monthly' and 'daily' responses, but no significance was found in the data. In assessing relationships between the number of language resources used and frequency of LEP patient visits, no significance was found when incorporating all resource categories into one analysis test $(\mathrm{p}=$ 0.6). However, when assessing only onsite resources, it was found that clinics that responded with higher frequency LEP patient visits ('weekly' and 'daily') had significantly more inhouse resources available, including both bilingual staff and staffed interpreters $(p=0.02)$.

Table 2: Comparative analysis of frequency of LEP patient visits and language resources at each clinic location. Dark-shaded boxes represent that given resource is utilized by health centers.

\begin{tabular}{|c|c|c|c|c|c|c|c|}
\hline & \multicolumn{2}{|c|}{ In-house Resources } & \multicolumn{2}{|c|}{ Outside Resources } & \multirow[b]{2}{*}{$\begin{array}{l}\text { Ad Hoc } \\
\text { Interpreters }\end{array}$} & \multirow{2}{*}{\begin{tabular}{|l|} 
Phone \\
Bilingual \\
Representat \\
ive
\end{tabular}} \\
\hline Responses & $\begin{array}{l}\text { Frequency } \\
\text { of LEP } \\
\text { Visits }\end{array}$ & $\begin{array}{l}\text { Bilingual } \\
\text { Staff }\end{array}$ & Interpreters & $\begin{array}{l}\text { Onsite } \\
\text { Interpreters }\end{array}$ & \begin{tabular}{|l} 
Remote \\
Interpreters
\end{tabular} & & \\
\hline 1 & RARELY & & & & & & \\
\hline 2 & RARELY & & & & & & \\
\hline 3 & RARELY & & & & & & \\
\hline 4 & RARELY & & & & & & \\
\hline 5 & RARELY & & & & & & \\
\hline 6 & MONTHLY & & & & & & \\
\hline 7 & MONTHLY & & & & & & \\
\hline 8 & MONTHLY & & & & & & \\
\hline 9 & MONTHLY & & & & & & \\
\hline 10 & MONTHLY & & & & & & \\
\hline 11 & MONTHLY & & & & & & \\
\hline 12 & MONTHLY & & & & & & \\
\hline 13 & MONTHLY & & & & & & \\
\hline 14 & MONTHLY & & & & & & \\
\hline 15 & MONTHLY & & & & & & \\
\hline 16 & MONTHLY & & & & & & \\
\hline 17 & MONTHLY & & & & & & \\
\hline 18 & MONTHLY & & & & & & \\
\hline 19 & MONTHLY & & & & & & \\
\hline
\end{tabular}




\begin{tabular}{|l|l|l|l|l|l|l|l|}
\hline 20 & MONTHLY & & & & & \\
\hline 21 & WEEKLY & & & & & & \\
\hline 22 & WEEKLY & & & & & & \\
\hline 23 & WEEKLY & & & & & & \\
\hline 24 & WEEKLY & & & & & & \\
\hline 25 & WEEKLY & & & & & & \\
\hline 26 & WEEKLY & & & & & & \\
\hline 27 & WEEKLY & & & & & & \\
\hline 28 & DAILY & & & & & & \\
\hline 29 & DAILY & & & & & & \\
\hline 30 & DAILY & & & & & & \\
\hline 31 & DAILY & & & & & & \\
\hline 32 & DAILY & & & & & & \\
\hline 33 & DAILY & & & & & & \\
\hline 34 & DAILY & & & & & & \\
\hline 35 & DAILY & & & & & & \\
\hline 36 & DAILY & & & & & & \\
\hline 37 & DAILY & & & & & & \\
\hline 38 & DAILY & & & & & & \\
\hline 39 & DAILY & & & & & & \\
\hline
\end{tabular}

Table 3: Summary of Table 2. Bilingual resources for LEP patients compared to frequency of LEP patient visits.

\begin{tabular}{|l|l|l|l|l|}
\hline $\begin{array}{l}\text { Frequency of LEP } \\
\begin{array}{l}\text { Visits (number of } \\
\text { participating } \\
\text { clinics) }\end{array}\end{array}$ & $\begin{array}{l}\text { In-house Resources } \\
\text { (clinics with resource } \\
\text { available / total } \\
\text { clinics per } \\
\text { frequency) }\end{array}$ & $\begin{array}{l}\text { Outside Resources } \\
\text { (clinics with resource } \\
\text { available / total } \\
\text { clinics per } \\
\text { frequency) }\end{array}$ & $\begin{array}{l}\text { Ad Hoc } \\
\text { Interpreters } \\
\text { (clinics with } \\
\text { resource available } \\
\text { / total clinics per } \\
\text { frequency) }\end{array}$ & $\begin{array}{l}\text { Phone: Bilingual } \\
\text { Representative } \\
\text { (clinics with } \\
\text { resource available } \\
\text { / total clinics per } \\
\text { frequency) }\end{array}$ \\
\hline Rarely (5) & $3 / 5$ & $5 / 5$ & $1 / 5$ & $0 / 5$ \\
Monthly (15) & $3 / 15$ & $14 / 15$ & $7 / 15$ & $1 / 15$ \\
Weekly (7) & $6 / 7$ & $7 / 7$ & $1 / 7$ & $3 / 7$ \\
Daily (12) & $7 / 12$ & $11 / 12$ & $7 / 12$ & $0 / 10$ \\
\hline
\end{tabular}

\section{Preferences and perceptions of working with LEP patients and Interpreter Agencies}

Quantitative survey data identified various trends in the preferences that clinics had when working with patients of limited English proficiency. Most responding clinics were satisfied overall with the interpreter agency they used and agreed that the interpreters themselves were professional and improved the experiences of LEP patient visits. Further, half of the survey responses agreed that interpretation services had improved in recent years. Yet, 55\% of survey respondents reported that their health facility preferred the use of bilingual clinical staff for managing LEP patient appointments, instead of relying on 
interpreter agencies. When working with interpreters, the majority of respondents reported that their clinical staff preferred to work with onsite interpreters, rather than remote interpreters by telephone or video call. Further, most respondents agreed that their communities might benefit if professional trainings were available for community or staff to become certified as medical interpreters.

Few respondents admitted that any lack in interpreter availability had ever been discussed during managerial board meetings, and only $27 \%$ of respondents admitted that cost had/has been an issue when hiring outside interpreters.

Table 4: Preferences and perceptions for working with LEP patients and $3^{\text {rd }}$ party interpreter agencies

\begin{tabular}{|c|c|c|c|}
\hline Perception & Agree & Disagree & $\begin{array}{c}\text { Non- } \\
\text { Applicable }\end{array}$ \\
\hline $\begin{array}{l}\text { Preferences when working with LEP patients: } \\
\qquad \quad \begin{array}{l}\text { We prefer to use our own clinic personnel, rather than outside } \\
\text { interpretive services. }\end{array}\end{array}$ & $55 \%$ & $30 \%$ & $15 \%$ \\
\hline $\begin{array}{l}\text { Perceptions of working with interpretation agencies: } \\
\text { - We are satisfied overall with the interpretation services we } \\
\text { use for providing quality care to LEP patients. } \\
\text { The interpreters are professional, punctual and overall } \\
\text { improve the quality of care we provide to our patients. } \\
\text { - Over the past five years, the quality and availability of } \\
\text { interpretive services has greatly improved in our clinic. } \\
\text { - Interpretive services are very expensive; this deters us from } \\
\text { heavy reliance on their services. } \\
\text { - We prefer to use in-person interpreters more so than remote } \\
\text { interpreters. } \\
\text { Lack of adequate interpretive services has been a discussion } \\
\text { in past staff/board meetings. }\end{array}$ & $\begin{array}{l}67 \% \\
76 \% \\
52 \% \\
27 \% \\
64 \% \\
21 \%\end{array}$ & $\begin{array}{l}21 \% \\
9 \% \\
24 \% \\
52 \% \\
21 \% \\
52 \%\end{array}$ & $\begin{array}{l}12 \% \\
15 \% \\
24 \% \\
21 \% \\
15 \% \\
27 \%\end{array}$ \\
\hline $\begin{array}{l}\text { Opportunity for more onsite interpreters within community: } \\
\text { - Our clinic and our community would benefit if an affordable } \\
\text { interpretation certification course was available to our staff, or } \\
\text { to members of our community. }\end{array}$ & $58 \%$ & $18 \%$ & $26 \%$ \\
\hline 0.05 & & & \\
\hline
\end{tabular}




\section{Interview responses}

Seven interviews provided a deeper understanding of 11 different clinics and hospitals around the state. Interviews came from a wide range of administrative staff, including clinic managers/directors, Patient Coordinators and Program Coordinators. Responses showed a variation in the frequency of patient visits where there was a language barrier. When compared to completed survey responses, interviewees came from clinics that reported all four frequencies of LEP patient visits. Further, responses showed a range of preferred languages spoken by their patients; all respondents commented that Spanish was the primary language spoken by LEP patients within their clinic(s). Additional responses included American Sign Language, Arabic, Chinese, Somali and Filipino. 


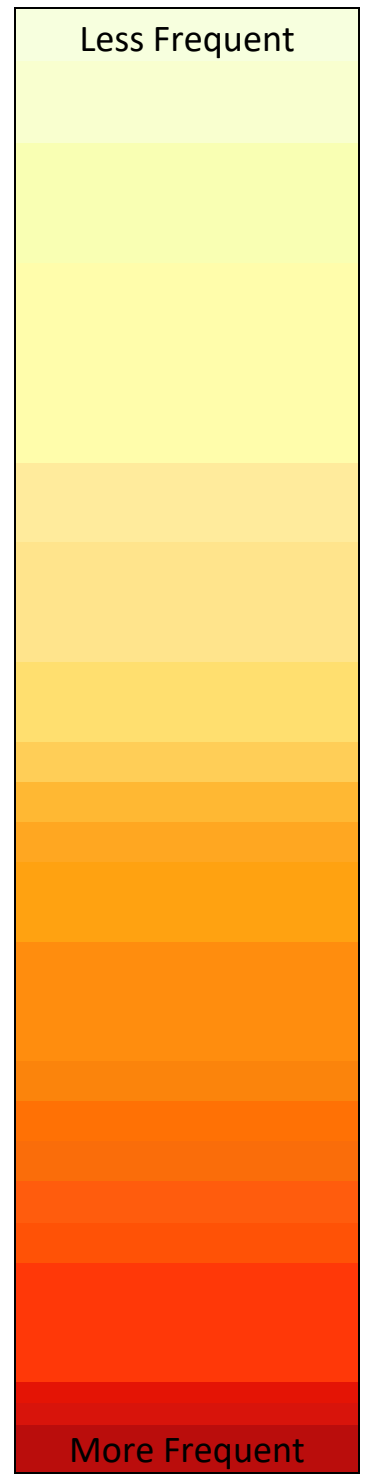

"Well I've been here for twenty years and we haven't used it yet."

"We have a large county, a very small population, a very small percentage of Hispanic, and no other foreign language is present."

"But that's very rarely called for, almost all of our Hispanic population are fluent in English as well."

"Blue River doesn't really have any ethnic population that I'm aware of."

"We do not have a large population of languages other than English. We do have a couple Chinese, some Spanish and there's a sign language patient."

"Three to five percent range."

"In our community, there is some Spanish-speaking population."

"Pendleton doesn't have a huge Spanish-speaking population, but we're seeing more and more patients at our clinic that are Spanishspeaking."

"I would say probably, roughly eight to ten percent."

"But a lot of our patients, most of our patients sometimes do come here. There are - some of them are self-pay. They're Hispanic, they don't speak English..."

Figure 5: Clinic staff express in their own words their familiarity to working with patients of limited English-speaking proficiency, within their health care centers of Rural Oregon. 
Table 5: Emerging themes from interview data.

Note: for complete interview analysis, see Appendix B

\begin{tabular}{|c|c|}
\hline Categories & Reoccurring Themes \\
\hline Bilingual staff & $\begin{array}{l}\text { Importance of onsite communication } \\
\text { In some clinics, Spanish-speaking providers and care staff are a necessity. } \\
\text { In areas with large populations of primarily Spanish-speakers, bilingual staff allow } \\
\text { clinics to feel confident in their abilities to help patients. } \\
\text { Bilingualism is a valuable skill and is one that is not always easy to come by. } \\
\text { Being able to communicate directly with patients is preferred; language } \\
\text { concordance allows for this. }\end{array}$ \\
\hline Phone & 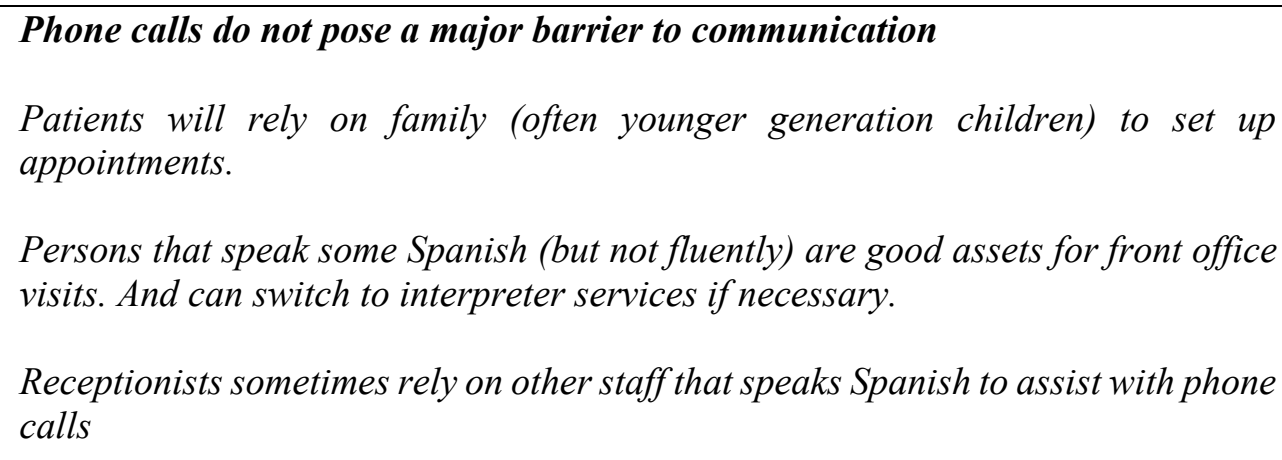 \\
\hline $\begin{array}{l}\text { Ad hoc } \\
\text { interpreters }\end{array}$ & $\begin{array}{l}\text { Ad hoc interpretation remains a common practice } \\
\text { In some clinics, ad hoc interpreters are used only in initial check-in of } \\
\text { appointments. } \\
\text { Clinic staff understand the dangers of using ad hoc interpreters. } \\
\text { Some clinics rely on ad hoc interpreters as a normal practice. } \\
\text { Policy of legality of ad hoc interpretation is not known in some cases. }\end{array}$ \\
\hline $\begin{array}{l}\text { Benefits to 3rd } \\
\text { party } \\
\text { interpreter } \\
\text { agencies }\end{array}$ & $\begin{array}{l}\text { Interpreter agencies are a valuable asset } \\
\text { Clinics feel supported by interpretation agencies. } \\
\text { Language services are a useful tool. It is easy to use and effective. } \\
\text { With more practice using remote interpretation, providers and staff become } \\
\text { accustomed to its functionality. }\end{array}$ \\
\hline
\end{tabular}




\begin{tabular}{|c|c|}
\hline Categories & Reoccurring Themes \\
\hline $\begin{array}{l}\text { Interpreters: } \\
\text { onsite vs. } \\
\text { remote }\end{array}$ & $\begin{array}{l}\text { Preference for onsite interpretation, despite limited resources } \\
\text { Clinic staff prefer in-person interpreters over remote. } \\
\text { In-person interpreters are easier to work, more time efficient, and it is helpful to } \\
\text { be able to double-check that everything was understood/heard properly. } \\
\text { Onsite interpreters are not commonly used. This is because they are unavailable. } \\
\text { For ASL, in-person interpretation is necessary (when video is unavailable). } \\
\text { However, they are not always available. }\end{array}$ \\
\hline $\begin{array}{l}\text { Interpreters: } \\
\text { Over-the- } \\
\text { phone } \\
\text { interpreting vs. } \\
\text { video remote } \\
\text { interpreting }\end{array}$ & $\begin{array}{l}\text { Preference for video interpretation } \\
\text { Staff prefer to use VRI over OPI. } \\
\text { VRI feels more personable, is less awkward, and all parties can more easily speak } \\
\text { (including family in the room). } \\
\text { Most clinics do not have access to video technologies and rely on phone } \\
\text { interpretation. }\end{array}$ \\
\hline $\begin{array}{l}\text { Challenges: } \\
\text { Insufficient } \\
\text { resources }\end{array}$ & $\begin{array}{l}\text { Lacking bilingual/certified staff and in-person interpreters } \\
\text { Bilingual staff (especially Spanish speaking) is perceived as a missing resource in } \\
\text { clinics. } \\
\text { Some clinics that lack bilingual providers will rely on uncertified bilingual staff } \\
\text { for interpretation. } \\
\text { Better communication is necessary to make sure that staff is available to interpret } \\
\text { for providers and care staff. } \\
\text { Bilingual staff lacks certification, but are heavily relied on for interpretation. } \\
\text { In-person interpreters travel long distances to assist clinics with LEP patients. }\end{array}$ \\
\hline $\begin{array}{l}\text { Challenges: } \\
\text { CCOs }\end{array}$ & $\begin{array}{l}\text { Irregularities in CCO language resources/reimbursements } \\
\text { Some CCOs are challenging to work with, with regards to reimbursing clinics for } \\
\text { costs of interpreters. } \\
\text { Some CCOs do provide language services to their clinics. But others only } \\
\text { reimburse for costs of interpreter expenses. Clinics feel CCOs should provide } \\
\text { those services. }\end{array}$ \\
\hline
\end{tabular}




\begin{tabular}{|c|c|}
\hline Categ & Reoccurring Themes \\
\hline $\begin{array}{l}\text { Challenges: } \\
\text { certification }\end{array}$ & $\begin{array}{l}\text { Certification is expensive and challenging to obtain } \\
\text { Certifying bilingual staff is an obstacle that some feel makes it more challenging } \\
\text { for their staff to treat patients. } \\
\text { Certification processes are expensive and can especially be difficult for smaller } \\
\text { clinics. } \\
\text { Some staff have been awarded scholarships for courses. Additional scholarships } \\
\text { would allow more staff to meet the requirements of the state. }\end{array}$ \\
\hline $\begin{array}{l}\text { Community: } \\
\text { working } \\
\text { together with } \\
\text { other clinics in } \\
\text { the area }\end{array}$ & $\begin{array}{l}\text { Rural communities collaborate limited resources to meet needs } \\
\text { Community partnerships form a network of support, these are crucial when } \\
\text { resources are limited. } \\
\text { In small communities, limited staff move around to different clinics to serve } \\
\text { patients. Having any bilingual staff/providers means patients in all clinics can be } \\
\text { seen. } \\
\text { In some communities, specific clinics have bilingual staff/providers. Those clinics } \\
\text { seems to serve more Spanish-speaking patients. } \\
\text { When LEP patients are referred to a specialist, providers will make sure to make } \\
\text { a note for language services on referral. } \\
\text { Bilingual staff will move between departments or go with patients to other } \\
\text { clinics/hospitals to provide language support. }\end{array}$ \\
\hline $\begin{array}{l}\text { Perception: } \\
\text { patients prefer } \\
\text { bilingual staff }\end{array}$ & $\begin{array}{l}\text { LEP patients prefer onsite language concordance } \\
\text { Clinic staff perceive that LEP patients might prefer to work with bilingual staff } \\
\text { versus interpreters. } \\
\text { Staff perceives higher LEP patient volume at clinics with more onsite resources. } \\
\text { LEP patients will travel to be seen by a Spanish-speaking provider. }\end{array}$ \\
\hline $\begin{array}{l}\text { Community: } \\
\text { big hospital } \\
\text { support }\end{array}$ & $\begin{array}{l}\text { Small health centers are significantly impacted by costs associated with language } \\
\text { resources } \\
\text { Small clinics face harder challenges with financial burden of interpretation and } \\
\text { certification of bilingual employees. } \\
\text { Large hospital organizations can financially assist clinics with language services. } \\
\text { Or, some larger hospitals will provide services to their clinics. }\end{array}$ \\
\hline
\end{tabular}




\begin{tabular}{|l|l|}
\hline Categories & Reoccurring Themes \\
\hline $\begin{array}{l}\text { Perception: } \\
\text { growth population }\end{array}$ & $\begin{array}{l}\text { LEP populations are growing } \\
\text { Clinic staff believes that LEP population growth means an increased need for } \\
\text { certified bilingual staff. } \\
\text { Having more trained interpreters for in-person visits would help with increasing } \\
\text { LEP populations. }\end{array}$ \\
\hline
\end{tabular}

\section{Discussion}

\section{LEP persons speak mostly Spanish}

Survey responses showed a resounding presence of Spanish as the primary language spoken by patients that do not speak English well. This was expected, as Spanish is the second-most spoken language in the state, and the largest percentage of LEP persons in Oregon speak Spanish as their primary language (LEP.gov, 2020; U.S. Census Bureau, 2015). Responses came from 18 counties in the state and modeled the relationship between LEP patient volume and language resources; however, it did not reflect a complete assessment of all health facilities' experiences from working with patients of limited English.

\section{Increases in LEP patient visit frequencies means more onsite language resources}

Data from Tables 2 and 3 suggested that clinics that have higher volumes of patients of limited English have more in-house (onsite) resources available for their patients. This included both bilingual staff as well as staff members that were certified medical interpreters. Health facilities that responded with 'daily' or 'weekly' LEP patient visits had significantly more onsite staff and bilingual resources for their patients than respondents that marked LEP patient visits every month or less than every month ('weekly' and 'rarely') $(\mathrm{p}=0.02)$. 


\section{Live/onsite interpretation is preferred - including ad hoc and uncertified interpreters}

When assessing survey responses to clinics' preferences for working with LEP patients, Table 4 shows that $55 \%$ of survey respondents agreed that their clinics preferred to use their own staff members for best serving their patients of limited English proficiency. Interviews present similar findings. When speaking with clinical staff, respondents felt that high LEP patient volumes were best met when staff members and providers spoke Spanish. A Patient Coordinator from Coos Bay shared that, without staff members that spoke fluent Spanish and could readily assist patients, "I honestly couldn't tell you what they would do."

Many (46\%) of all survey respondents admitted that they sometimes rely on the assistance of ad hoc interpreters during LEP patient appointments. Research has identified that the use of untrained interpreters results in higher frequency of inaccurate interpretations, which can lead to medical errors and has also been linked with a decrease in patient satisfaction (Cox et al., 2019; Wang, 2016). Some interviewees knew of the safety and legal repercussions that are connected with the use of untrained medical interpreters, however others shared that their clinic often asked patients to bring along someone that could assist with interpretation.

Interviews may have provided an answer to this high number. For instance, one clinic manager explained that family and friends often assisted patients with LEP for checking in for appointments, completing history paperwork, etc. However, "when it comes time to talk diagnosis [sic] and treatment," a Director of Physician Clinics in Pendleton shared that they would always use a professional. This may suggest that clinics use the assistance of family members only in initial steps of appointments, but not during the actual provider-patient interactions. In reviewing survey responses, it is possible that respondents included these interactions when completing the survey. However, other interview responses suggested that 
the use of ad hoc interpreters was a common practice for providing care in their clinic. Past research has suggested that ad hoc interpreters have been relied on more heavily than professional interpreters in some hospital establishments (Schenker et al., 2011). Other studies have identified that hospital staff are unaware of policies and resources available for patients of limited English Proficiency and have concluded that increasing staff awareness of available resources and patient safety, with regards to the use of ad hoc interpreters could benefit both patients and medical staff (Mayo et al. 2016; Taira et al., 2020). These data suggest a preference for live-person interpretation whenever possible. The tendency to rely on bilingual staff (even when not certified) and ad hoc interpreters rather than professional remote interpreters is a trend that has been identified in other studies as well, and seems to be a trend that has continued to exist in and around rural regions of Oregon (Taira et al., 2020).

\section{LEP patient phone calls are not a significant barrier to communication}

Very few of the participating clinics had phone recordings that prompted the availability of Spanish-speaking representatives. This does not reveal any specific gap in resources for LEP patient assistance, however, as no research could be identified that linked bilingual receptionists and quality of care when there is a language barrier. Clinics, as well as patients, have identified methods for ensuring that patients are understood and that appointments are scheduled properly. Interview responses suggested that patients often use a family member that speaks English well to call and set up appointments. Clinic respondents suggested that staff will transfer calls to other receptionists if a patient speaks Spanish and a bilingual receptionist is available, or will find bilingual staff, when available, to assist with calls. Further, other clinics commented that they had staff that spoke some Spanish, although they were not fluent, but conversant enough to assist with front-of-house duties. Calling an 
interpreter line was often the last sought resource that receptionists would use for assisting LEP patients over-the-phone.

\section{Interpretation/translation agencies remain a valued resource}

However, even if onsite interpretation is preferred, it is not a realistic solution for all health centers around the state. Hiring providers can be challenging none-the-less, and seeking bilingual medical professionals is not always a feasible option. Further, some parts of Oregon have patient populations that are primarily English-speaking and find themselves with very few instances when language resources are necessary, such as for that "one off French speaker or something," as one clinic manager phrased it. For these scenarios, technology has allowed for professional interpretation to occur at any hour of the day, with the assistance of remote interpretation and translation agencies. Survey responses showed that $95 \%$ of participating clinics contract through $3^{\text {rd }}$ party interpretation/translation companies to ensure quality care for their patients.

Most rural clinics were impressed and satisfied with the agency they work with. $67 \%$ responded by saying they were satisfied overall and $76 \%$ were impressed and satisfied with the interpreters themselves. Interview responses also mirrored satisfaction with interpretation/translation companies. As one clinic manager explained, "we looked at a bunch of different services and, the thing that we liked about it was that you could use it 24-hours a day, but you could also — there were so many languages available." Growth and development have occurred in the interpretation industry at a steady rate over the past ten years and has resulted in competitive quality services in the United States (Cabrera, 2017). Continuous advancements in technology, as well as growth of the industry may have resulted in improvements of quality of services. $52 \%$ of survey respondents agreed that the quality of interpretation/translation through $3^{\text {rd }}$ party agencies had improved over the past five years. 


\section{Challenges associated with language resources}

Limited video technology - Interview responses identified a number of challenges that rural clinics face when trying to provide quality care to their patients with limited English proficiency. One area of interest was the use of video remote interpretation (VRI). VRI has been an area of technological expansion for the interpretation industry (Alley, 2012). Research has suggested that video remote interpretation offers improvements in communication and comprehension between physician and Spanish-speaking patient families, and has suggested that video-based interpretation shows promise for improving patient care for Spanish-speaking populations (Lion et al., 2015). Some interviewees agreed with current research in that the use of video interpretation offered certain benefits that improved communication that were not offered with conventional over-the-phone interpretation (Marshall et al., 2019). Such benefits might include that "everybody in the room can talk and see each other," as one respondent explained.

One drawback to the survey data was that the survey did not distinguish between types of remote interpretation used in clinics and hospitals; however, interview data suggests that most clinics do not have access to video interpretation technologies. Only one respondent (14\%) said that their clinic had the ability to use video for remote interpreting. Most relied exclusively on over-the-phone services when remote interpretation was necessary. As one clinic in Eastern Oregon put it, "we're just not advanced enough to do video conferencing yet." Future research that identifies a more accurate estimation of the actual reliance of VRI across rural Oregon would be an interesting study.

Costs of services and reimbursements from CCOs - As Title VI of the Civil Rights Act explains, language assistance services must be offered to patients free of charge, and therefore, costs fall back onto health care providers, facilities, and the health industry (Jacobs 
et al., 2018; Medicaid.gov, 2020). However, federal financial assistance programs, such as Medicaid and the Children's Health Insurance Program (CHIP) can reimburse providers for the costs of language interpreters, after providers cover the up-front costs of the services (Jacobs et al., 2018). This varies on a state-to-state basis, and states are not required to reimburse providers for the cost of language services (Medicaid.gov, 2020). Oregon Administrative Rule 410-141-3220(9) states that Coordinated Care Organizations (CCOs) are required to ensure that free quality interpretation services are available to individuals with a disability or that are LEP (OHA, 2020a; Oregon Secretary of State, 2020).

However, CCOs are not required by law to reimburse providers or clinics for health care interpretation services; in Oregon, a large proportion of the CCOs do pay for interpretation services, however, funding is often allocated from federal Medicaid reimbursements and inconsistencies in patient's coverage can lead to inconsistencies in CCOs' ability to reimburse costs (K. Wilson, personal communication, May 13, 2020). A conversation with Kweku Wilson, Ph.D., from the Oregon Health Authority led to the understanding that Oregon does not require CCOs to reimburse providers for the costs associated with hiring interpreters (K. Wilson, personal communication, May 13, 2020). 15 other states, however, do manage to arrange federal and state funds in order to pay for these services, and Oregon has current policy initiatives that could address this gap in payments (perhaps following in the footsteps of these other states) (K. Wilson, personal communication, May 13, 2020). 27\% of survey respondents indicated that expense of providing language services had been a concern in their facility. Interviews suggested contradictory support from CCOs in reimbursing for the costs of language services. Some felt confident that their patients would be covered by the Oregon Health Plan, saying "we call their line and we give them their medical ID number and then they bill them versus us 
directly." However, other health centers felt that CCO support in reimbursing costs for language services had not been satisfactory, and that there had been "real difficulties" with trying to get $\mathrm{CCO}$ coverage for interpretation service reimbursement. The policy initiatives mentioned by Dr. Wilson might remove these payment gaps for Oregon in the coming years.

Costs seem to impact privately-owned practices more so than health facilities that are owned or partnered with large health organizations. This logically makes sense; but as irregularities in $\mathrm{CCO}$ coverage and reimbursement policies remain variable, small organizations will suffer from having fewer financial resources.

Certification of bilingual staff - In addition to the legal obligation of providing an interpreter to those who need one, Title VI states that interpreters must be a qualified healthcare interpreter (OHA, 2020a). There are obvious benefits to standardizing and ensuring that health care interpreters are trained to follow protocols for providing quality, meaningful and professional care; however, clinic staff felt that some of these requirements have made it more challenging for their staff to be able to provide care to their patients in the past.

Professional care staff that are bilingual are not required under any legislation to be certified as bilingual, when speaking directly with a patient about care. However, under these circumstances, a bilingual professional could not assume the role as interpreter, without proper training and certification (S. Molano, personal communication, June 7, 2020). In small and rural facilities, having bilingual staff that are also trained as interpreters could be a valuable use of resources. However, the costs associated with the certification processes were identified as a challenge that many clinics had faced. Some bilingual professionals feel that their expertise in the medical field and their years of experience working with Spanishspeaking patients has made them feel comfortable for all medical situations that may arise - 
including interpreting for others during patient visits. One interviewee, a Clinic Manager from the Oregon Coast, felt that an abbreviated certification process for one of their clinic's already trained and practiced bilingual nurses would have been sufficient, as well as more affordable, saying, "it would be nice if they would just test her. Speak to her and see if she has it, without making her go through all that." However, language fluency does not necessarily mean comprehension of the complex medical terminology that may arise during medical appointments. Bilingual staff that are trained to be effective interpreters can be a valuable resource; however, feasible testing strategies to assess bilingualism could benefit clinic staff by ensuring staff is fluent in medical terminology, as well as instruct/remind staff of proper practices when interpreting for patients with LEP.

One interviewee shared that she had been interpreting for her clinic for years, and felt that her services should be met with increased pay when she interprets for patients and providers. Indeed, some organizations do reward their bilingual staff for their assistance. OHSU is one example of a care organization that tests staff for bilingual ability and offers increased pay to their bilingual employees (S. Molano, personal communication, June 7, 2020). No legislation in Oregon mandates that bilingual health professionals be paid for their communication abilities, however.

The use of uncertified/unqualified medical interpreters is a somewhat common practice, assured Susy Molano, the Executive Director of the Oregon Health Care Interpreters Association (OHCIA) (S. Molano, personal communication, May 18, 2020). In a conversation with Ms. Molano, she shared her expert perception that many of the medical staff that work as interpreters during LEP patient visits are not certified or qualified by the OHA, an issue that needs to be addressed. House Bill 4115 was introduced into the 2020 Oregon Legislative Assembly and aimed to create legislature that would require that all 
persons assisting patients with LEP are certified or qualified by the OHA (Oregon Legislative Assembly, 2020; S. Molano, personal communication, May 18, 2020). This bill would have held CCOs more accountable of ensuring that quality of care is maintained for patients of limited English proficiency when hiring out interpreters as well as would have enforced standards of practice that are taught to health care interpreters during OHA-approved certification courses (S. Molano, personal communication, May 18, 2020). Unfortunately, this bill was not passed; Susy Molano and the OHCIA are now working on another proposal for 2021 that would create a Licensing Board for health care interpreters (HCIs) and would require that all interpreters be certified (S. Molano, personal communication, June 7, 2020). However, while ensuring that health care interpreters (HCIs) are certified, this bill does not address issues of the expenses of the certification process.

\section{Rural community collaboration}

Rural communities face restricted access to some resources that might be considered readily available in urban areas. Therefore, rural communities may use alternative means to meet the needs of their people. In a health care context, this might mean working together with other clinics in the area. A past study on rural hospitals and Spanish-speaking LEP patients found that the participating hospitals often worked within their communities' schools, sheriff departments and even correctional facilities to form partnerships that could benefit LEP patients and their communities (Torres et al., 2008). Interview data from this study suggested that health facilities in rural Oregon also benefit from inter-clinic partnerships. Working with others to serve LEP patients seems to offer stronger support to communities.

Multiple interviewees mentioned other neighboring clinics that often saw the majority of the Spanish-speaking populations within their community. Under the perception that these ambulatory clinics had more Spanish-speaking staff and providers, managers agreed that 
these clinics were more suited to serving the community of Spanish speakers. Some mentioned that they would refer LEP patients to the other clinic, believing that the needs of the patients would be more easily met. In another rural area, a respondent shared that certified interpreters in their clinic would go to assist the local hospital departments on a by-need basis. Further, another respondent remembered traveling with a Spanish-speaking patient from their clinic over to the hospital to assist with admitting the patient. In another, the community had one bilingual provider. This spokesperson said that their providers would travel multiple days per week to neighboring towns to the other community clinics, and that Spanish-speaking patients would schedule their clinic visits on days when the bilingual provider was available at their clinic. Smaller communities in Oregon seem to have limited certified language personnel; this leaves the few certified interpreters and bilingual staff with a difficult task of trying to meet the needs of the whole community. In some instances, this means traveling to other departments, other clinics, or even other towns. In other instances, bilingual staff are centralized in specific clinics and Spanish-speaking patients are referred or recommended to seek services there.

\section{LEP patients prefer language concordance}

Responding managers also perceived that Spanish-speaking patients preferred to work with staff and providers that spoke Spanish. Research has suggested that language concordance between Spanish-speaking patients and physicians is positively correlated with improved perception of care, higher rates of following doctors' orders, higher levels of glycemic control of diabetic patients, and higher quality of care for diseases including cancers, diabetes, pain management and primary care (Diamond et al, 2019; Parker et al, 2017). One Clinic Director said that Spanish-speaking patients would even travel from neighboring cities and towns in 
order to work with the bilingual staff and certified interpreters that their clinic had available. Past studies have identified that persons of limited English proficiency will often travel longer distances to be seen by language concordant physicians (Cordasco et al., 2011; Wilson et al., 2005) and this study seems to suggest that these trends continued to exist for LEP patients in rural Oregon.

\section{Large medical organizations offer resources for their rural clinics}

Rural clinics that receive support and aid from large hospital establishments are often supported with language services from these large hospitals. One example are the ambulatory clinics associated with Oregon Health and Science University. One rural clinic interviewed was associated with the university and benefitted by having their interpreter line available for use, as well as brochures, posters and documents from OHSU that were written in English as well as Spanish. However, other rural health clinics do not have as strong of support, and the financial burdens of interpreter services, or certifying bilingual staff as interpreters was challenging.

\section{Growing LEP populations means increased need of interpreters}

Finally, when speaking with managerial staff about perceived rises in LEP patient populations at their clinics, four of seven (57\%) believed that patient populations were increasing. With rises in LEP patient visits, data from surveys and interviews suggests a need for increasing the number of trained interpreters in rural parts of the state. One method to do so would be by implementing state-funded certification courses to bilingual clinic staff. One interviewee mentioned that they had received a scholarship from OHCIA for completing the 60-hour online training course for medical interpretation, part of the certification process for becoming a certified or qualified medical interpreter in Oregon. The OHCIA has scholarship opportunities available, however it does not receive any grants from the state for providing 
these scholarships (S. Molano, personal communication, May 18, 2020). Instead, OHCIA collaborates with WorkSource Oregon, an equal opportunity employer program that receives federal funds that can be allocated to training persons in the health care field (including interpreting). WorkSource Oregon assists the OHCIA in providing scholarships for their 60hour HCI training course (S. Molano, personal communication, June 7, 2020). If the state offered additional scholarships or courses for training bilingual staff members and members of the community, this could significantly increase the number of certified interpreters in rural parts of the state. When answering "Our clinic and our community would benefit if an affordable interpretation certification course was available to our staff, or to members of our community," $58 \%$ of survey respondents agreed. Further, $71 \%$ of interviewees agreed that a certification course such as this would benefit their community.

In 2011, a pilot program in New Jersey implemented a regional one-day training program for bilingual medical staff on medical interpretation. Findings from the success of the program showed significant increases in staff's knowledge of proper interpreting techniques and practices for providing interpretive care, a decrease in the region's use of remote interpretation, as well as an increase in the number of face-to-face interpretations (HRET of Jew Jersey, 2011). A similar study could benefit hospitals and clinics of Oregon. Future research could identify best strategic practices for implementing such a study here in the state of Oregon.

\section{Limitations}

Data from this study were self-reported and thus, actual practice may be different from the answers provided. Data were collected from 33 health facilities in the state, located in mainly north, northeast and coastal counties of Oregon. A wide-spread investigation that explores a 
larger proportion of health centers across Oregon could be beneficial. Many counties did not participate in this study and receiving data from all counties would be beneficial. Additionally, this study focused primarily on Spanish-speaking patients in the state, however this does not represent the entire LEP population in Oregon.

This investigation was completed pre- the COVID-19 pandemic. The rippling effects of the virus are still very much unknown, and it is likely that the way medicine is practiced in the United States as well as around the world will never quite be the same as before. Therefore, the results of this study will have to be considered and viewed through a lens that allows their implications to remain useful in whatever context deemed necessary.

Lastly, this investigation was completed as an undergraduate thesis; a follow-up investigation piloted by the Oregon Health Authority would allow for a more thorough investigation of this subject, as well as ensure quality research methods are followed and maintained.

\section{Avenues for future research}

In my investigation, I came across endless directions for future research on this important topic. In my conversations with Susy Molano from the OHCIA and Kweku Wilson from the OHA, I learned that community care organizations are an essential access point to rural health clinics around the state. Enforcing changes in practice at the CCO-level, such as ensuring that interpreters are qualified or certified, or requiring for CCOs to reimburse all costs associated with language resources seems to be one of the most effective methods for a broadreaching effect of improving and ensuring quality practices are maintained. An exploration of how practices of CCOs vary across the state, with specific focus on each CCO's use of hiring out interpreters and how often CCOs are contacted by their clinics to request 
interpreters could prove beneficial for establishing a standard of practice on this issue in Oregon.

This study was the first of its kind (that I could identify) that was directly interested in how frequency of LEP patient visits affects language resource availability for clinics and hospitals, especially in rural settings. However, a larger sample size of rural clinics and hospitals could provide important findings and might identify practices that other rural health facilities could use to better serve their own limited English populations.

The COVID-19 pandemic has shown light on countless holes in the health care system in the United States. These issues start at the very top and trickle down through many governmental pools. One area of exploration includes how COVID-19 has changed language access for persons with LEP. An assessment of LEP patients' perceptions of health care visits pre- and post the pandemic could prove beneficial for ensuring that mistakes are corrected and that gaps are covered for the future. Indeed, there are many lessons to be learned from these extraordinary times.

\section{Conclusions}

Clinics in rural Oregon that see higher frequencies of LEP patient visits have significantly more onsite languages resources available, including bilingual staff and onsite interpreters. Clinics seem to prefer to work with their own in-house staff, more so than with $3^{\text {rd }}$ party interpretation agencies, as well as prefer to have onsite interpreters rather than remote interpreters. However, data suggest that in-person interpreters are uncommon in rural parts of Oregon. Implementing a free or reduced-cost training course for bilingual staff and community members in rural parts of the state could prove beneficial in increasing the number of certified medical interpreters in rural areas. This could prove to be a necessary 
step in ensuring that all Oregonians receive the quality and meaningful care they deserve across the state. 


\section{References}

Alley, E. (2012). Exploring remote interpreting. International Journal of Interpreter Education, 4(1), 111-119.

Cabrera, T. (2017). The translation and interpreting industry in the United States. Observatorio Reports, ISSN 2373-874X (online), 1-59.

Cohen, A., Rivara, F., Marcuse, E., Mcphillips, H., \& Davis, R. (2005). Are language barriers associated with serious medical events in hospitalized pediatric patients? Pediatrics, 116(3), 575-579.

Cordasco, K., Ponce, N., Gatchell, M., Traudt, B., \& Escarce, J. (2011). English language proficiency and geographical proximity to a safety net clinic as a predictor of health care access. Journel of Immigrant Minority Health, 13: 260-267. https://doi.org/10.1007/s10903-010-9425-6

Cox, A., Rosenberg, E., Thommeret-Carriere, A., Huyghens, L., Humble, P., \& Leanza, Y. (2019). Using patient companions as interpreters in the emergency department: An interdisciplinary quantitative and qualitative assessment. Patient Education and Counseling, (April), 1-7.

Diamond, L., Izquierdo, K., Canfield, D., Matsoukas, K., \& Gany, F. (2019). A systematic review of the impact of patient - physician non-English language concordance on quality of care and outcomes. Journal of General Internal Medicine, 1591-1606. https://doi.org/10.1007/s1 1606-019-04847-5

Douthit, N., Kiv, S., Dwolatzky, T., \& Biswas, S. (2015). Exposing some important barriers to health care access in the rural USA. Public Health, 129(6), 611-620.

DuBard, C., \& Gizlice, Z. (2008). Language spoken and differences in health status, access to care, and receipt of preventive services among US Hispanics. American Journal of Public Health, 98(11), 2021-2028.

Fernandez, A., Schillinger, D., Grumbach, K., Rosenthal, A., Stewart, A., Wang, F., PerezStable, E. (2004). Physician language ability and cultural competence: An exploratory study of communication with Spanish-speaking patients. Journal of General Internal Medicine, 19, 167-174. 
Health Research and Educational Trust of New Jersey. (2011). Interpreter training program for bilingual staff in healthcare: Report of Pilot Program Evaluation in Southern New Jersey. $\quad$ Retrieved from http://www.njha.com/media/54904/InterpreterTraining_ExecSummary.pdf

Isasi, C., Rastogi, D., \& Molina, K. (2016). Health issues in Hispanic/Latino youth. J Lat Psychol, 4(2), 67-82.

Jacobs, B., Ryan, A., Henrichs, K., \& Weiss, B. (2018). Medical interpreters in outpatient practice. Ann Fam Med, 16(1), 70-76.

Kaiser Family Foundation. (2020). Health and health care in the U.S. by race and ethnicity. Disparities Policy. Retrieved from https://www.kff.org/infographic/health-andhealth-care-in-the-u-s-by-race-and-ethnicity/

Kim, G., Aguado, C. X., Chiriboga, D. A., Jang, Y., Parmelee, P., \& Allen, R. S. (2011). Limited English proficiency as a barrier to mental health service use: A study of Latino and Asian immigrants with psychiatric disorders. Journal of Psychiatric Research, 45(1), 104-110.

Klugman, C., \& Dalinis, P. (2008). Ethical Issues in Rural Health Care. Johns Hopkins University Press, Baltimore.

Lion, K., Brown, J., Ebel, B., Klein, E., Strelitz, B., Gutman, C., Hencz, P., Fernandez, J., \& Manglone-Smith, R. (2015). Effect of telephone vs video interpretation on parent comprehension, communication, and utilization in the pediatric emergency department: A randomized clinical trial. JAMA Pediatrics, 169(12), 1117-1125.

LEP.gov. (2020). 2015 Language Map App. Retrieved from https://www.lep.gov/maps/lma2015/Final

LEP.gov. (2018). Limited English proficiency (LEP): A federal interagency website. Retrieved from https://www.lep.gov/video/video.html

Marshall, L., Zaki, A., Duarte, M., Nicolas, A., Roan, J., Fischer, A., Noyes, A., \& Flores, G. (2019). Promoting effective communication with limited English proficient families: Implementation of video remote interpreting as part of a comprehensive language services program in a children's hospital. The Joint Commission Journal on Quality and Patient Safety, 47(7), 509-516.

Mayo, R., Parker, V., Sherrill, W., Coltman, K., Hudson, M., Nichols, C., ... Pribonic, A. (2016). Cutting corners: Provider perceptions of interpretation services and factors 
related to use of an ad hoc interpreter. Hispanic Health Care International, 14(2), 7380. https://doi.org/10.1177/1540415316646097

Medicaid.gov. (2020). Translation and interpretation services. Centers for Medicare and Medicaid services, Baltimore, MD. Retrieved from https://www.medicaid.gov/medicaid/financial-management/medicaidadministrative-claiming/translation-and-interpretation-services/index.html

Oregon Health Authority. (2020a). Frequently asked questions regarding providing interpreter services to individuals who are deaf, deaf-blind, hard of hearing or individuals with limited English proficiency. Office of Equity and Inclusion, Portland, OR. Retrieved from https://www.oregon.gov/oha/OEI/Documents/FAQ\%20Language\%20Access\%20an d\%201557\%20V4\%2009.16.18.pdf

Oregon Health Authority. (2020b). Oregon Health Plan: Coordinated care organizations. Oregon.gov, Portland, OR. Retrieved from https://www.oregon.gov/oha/hsd/ohp/pages/coordinated-care-organizations.aspx

Oregon Legislative Assembly. (2020). House Bill 4115. Oregon State Legislature, Salem, OR. $\quad$ Retrieved from https://olis.oregonlegislature.gov/liz/2020R1/Downloads/MeasureDocument/HB411 $\underline{5 / \text { Introduced }}$

Oregon Office of Rural Health. (2019). ORH Brochure. ORH, Portland, OR. Retrieved from https://www.ohsu.edu/sites/default/files/2018-08/ORH\%20Brochure.pdf

Oregon Office of Rural Health. (2020). About rural and frontier data. ORH, Portland, OR. Retrieved from https://www.ohsu.edu/oregon-office-of-rural-health/about-rural-andfrontier-data

Oregon Secretary of State. (2020). Oregon Health Authority health systems division: Medical assistance programs - Chapter 410. Oregon State Archives, Salem, OR. Retrieved from https://secure.sos.state.or.us/oard/viewSingleRule.action?ruleVrsnRsn=264535

Parker, M., Fernández, A., Moffet, H., Grant, R., Torreblanca, A., \& Karter, A. (2017). Association of patient-physician language concordance and glycemic control for limited-English proficiency Latinos with type 2 diabetes. JAMA Internal Medicine, 177(3), 380-387. https://doi.org/10.1001/jamainternmed.2016.8648

Ruffenach, C., Worcel, S., Keyes, D. \& Franco, R. (2016). Latinos in Oregon: Trends and opportunities in a changing state. The Oregon Community Foundation, (August). 
Retrieved

from https://oregoncf.org/Templates/media/files/reports/latinos_in_oregon_report_2016.p $\underline{\mathrm{df}}$

Saldaña, J. (2013). The Coding Manual for Qualitative Researchers. Los Angeles, CA, SAGE Publications Ltd.

Schenker, Y., Pérez-stable, E. J., Nickleach, D., \& Karliner, L. S. (2011). Patterns of interpreter use for hospitalized patients with limited English proficiency. Journal of General Internal Medicine, 26(7), 712-717. https://doi.org/10.1007/s11606-010-1619$\mathrm{z}$

Taira, B. R., Torres, J., Nguyen, A., Guo, R., \& Samra, S. (2020). Language assistance for the care of limited English proficiency (LEP) patients in the emergency department: A survey of providers and staff. Journal of Immigrant and Minority Health, 22(3), 439447. https://doi.org/10.1007/s10903-019-00964-9

Torres, M., Parra-Medina, D., Bellinger, J., Johnson, A., \& Probst, J. (2008). Rural hospitals and Spanish-speaking patients with limited English proficiency. Journal of Healthcare Management, 53(2), 107-120.

Tschurtz, B., Koss, R., Kupka, N., \& Williams, S., (2011). Language services in hospitals: Discordance in availability and staff use. Journal of Healthcare Management, 56(6), 403-17; discussion 417-8.

U.S. Census Bureau. (2015). Detailed languages spoken at home and ability to speak English for the population 5 years and over for states: 2009-2013. 2009-2013 American Community Survey. Retrieved from https://www.census.gov/data/tables/2013/demo/2009-2013-lang-tables.html

U.S. Department of Health and Human Services Office of Civil Rights. (2019). Know the rights that protect us from discrimination based on race, color or national origin. Office of Civil Rights, Washington DC. Retrieved from https://www.hhs.gov/sites/default/files/ocr/civilrights/resources/factsheets/yourright sundertitleviofthecivilrightsact.pdf

Wang, X. (2016). The impact of using ad hoc interpreters and professional interpreters of hospital costs and patient satisfaction rates of limited-English-proficient patients in the emergency department. International Journal of Economics, Commerce and Management, IV(3), 245-257. 
Wasserman, M., Renfrew, M. R., Green, A. R., Lopez, L., Tan-McGrory, A., Brach, C., \& Betancourt, J. R. (2014). Identifying and preventing medical errors in patients with limited English proficiency: Key findings and tools for the field. Journal of Healthcare Quality, 36(3), 5-16.

Wilson, E., Chen, A., Grumbach, K., Wang, F., \& Fernandez, A. (2005). Effects of limited English proficiency and physician language on health care comprehension. Journal of General Internal Medicine, 20, 800-806. https://doi.org/10.1111/j.15251497.2005.0174.x

Zong, J., \& Batalova, J. (2015). The limited English proficient population in the United States. Migration Policy Institute, 1-9. 


\section{Appendix A}

- - - - - - - - - - - - - - - - - - - - - - - - - - - - - - - - - - - - - - - - - - - - - - - - - - - - - - - -

\section{Working with Patients with Limited English Proficiency in Your Community}

Thank you for taking the time to complete this brief evaluation form. Your feedback is greatly appreciated and will hopefully result in improvements to the availability and quality of language services where they are most needed.

* Required

1) What is the name of your clinic? In what city/town/county is it located? *

2) Does your clinic ever provide care for patients that speak English less than "very well"? *

Select only one.

— No, never

_ Yes, but only sometimes (1-2 patients per month, or less)

_ Yes, we work regularly with limited English patients (every week)

_ Every day, we serve limited English patients in our community

_ Other:

3) Besides English, what language(s) are spoken by patients in your clinic?

Check all that apply.

_ Spanish

_ Chinese (Mandarin and/or Cantonese)

_ Vietnamese

__ American Sign Language

French

_ Russian

_ Arabic 
_ Tagalog or other Pacific Island languages

_ Our patients generally speak English well

_ Other:

4) When a patient speaks limited English, our clinic...

Check all that apply.

_ Our clinicians are bilingual, so interpretive services are not usually necessary

_Relies mostly on staff/personnel to assist with translation and interpretation

_ Schedules appointments with 3rd party interpretation/translation service companies.

_ The patient usually brings a family member that can assist during the appointment

_ Our patients generally speak English

5) Does your clinic ever require the assistance of language interpreters/translators from 3rd party companies? (including in-person and phone/video interpretation)

Check all that apply.

- No, never

_ Sometimes, but not often (less than every month)

_ On average, about 1-2 times per month

_ Every week we require medical interpreters to help our patients and staff

_ Every day, we work with interpretive services

_ Other:

6) When outside interpreters/translators are necessary, these services are usually...

Check all that apply.

_ In-person, with certified medical interpreters

_ Over-the-phone/video call with certified medical interpreters

_ A family member or friend, that accompanies the patient

_ A staff member that is also a certified interpreter 
_ Our staff/personnel are bilingual, so outside resources are rarely necessary

_ Our patients generally speak English, so outside resources are rarely necessary

_ Other:

7) Which 3rd party company/companies do you use to assist with interpretation/translation services?

Check all that apply.

_ Passport to Languages

_ Linguava

_ Telelanguage Inc.

_ Interpreters Unlimited

_ Certified Languages International

_ TransPerfect

__ United Language Group

_ Other:

8) Please describe the overall satisfaction of language assistance availability and quality for your clinicians and staff?

- We are satisfied with the quality of medical interpreters we use
Disagree
Slightly Disagree
Agree
Highly Agree || Non-Applicable

- The interpreters are professional, punctual and overall improve the quality of care we provide to our patients

Disagree — Slightly Disagree — Agree — Highly Agree \| Non-Applicable

- When interpretive assistance has been unavailable, we have been forced to carry out appointments without a certified medical interpreter

Disagree — Slightly Disagree — Agree — Highly Agree I| Non-Applicable

- We would prefer to use in- person interpreters more so than over-the-phone interpreters

Disagree — Slightly Disagree — Agree —— Highly Agree \|| Non-Applicable 
- Lack of adequate interpretive services has been a discussion in staff meetings in the past.

Disagree _ Slightly Disagree __ Agree __ Highly Agree || Non-Applicable

- Interpretive services are very expensive; this deters us from heavy reliance on their services

Disagree — Slightly Disagree — Agree — Highly Agree I| Non-Applicable

- Over the past five years, the quality and availability of interpretive services has greatly improved in our clinic

Disagree — Slightly Disagree — Agree — Highly Agree \| Non-Applicable

- We prefer to use our own clinic personnel, rather than outside interpretive services

Disagree — Slightly Disagree —_ Agree —— Highly Agree \|| Non-Applicable

- Our clinic and our community would benefit if an affordable interpretation certification course was available to our staff, or to members of our community

Disagree — Slightly Disagree _— Agree —_ Highly Agree || Non-Applicable

9) Is there any other information you wish to provide about language assistance within your clinic?

10) Would you, or anyone in your clinic staff, be willing to provide further information by participating in a brief phone interview to explain experiences on this matter in more detail? *

Select only one.

- Yes

_ No, but thank you

11) If you are willing to participate in a phone interview, please provide your name, email and phone number; I will be in contact with you. Thank you 


\section{Appendix B}

Emerging themes from interview data

\begin{tabular}{|c|c|c|}
\hline \multirow[t]{2}{*}{ Categories } & In Vivo Quotes & Concluding Discussion \\
\hline & $\begin{array}{l}\text { we have a nurse practitioner coming, who can speak some } \\
\text { Spanish. And so that's going to be a little helpful. } \\
\text { we've focused on making sure we have staff that supports } \\
\text { them, with the Spanish-speaking population. } \\
\text { if they didn't have the person that works in the lab area to be } \\
\text { able to jump in and help out when they could, or one of our } \\
\text { other MAs who's a float. If she wasn't here, I don't, I honestly } \\
\text { couldn't tell you what they would do. } \\
\text { We actually had some emergency situations, but at that time, } \\
\text { I had a triage nurse who spoke fluent. She was actually } \\
\text { Spanish. So, she spoke it fluently and she was able to take } \\
\text { care of it. And that's what she did, because she's a triage } \\
\text { nurse. So, that worked really well } \\
\text { they have more Spanish-speaking or bilingual staff and } \\
\text { providers than in Pendleton. } \\
\text { We don't. But we always are pleased when we see that on } \\
\text { their CV. It's difficult, hiring providers anyway, so that is not } \\
\text { a requirement, but it's always a pleasure to see that. } \\
\text { I do have two Spanish-speaking providers. And then I have } \\
\text { two support staff, so receptionists, that are bilingual. I } \\
\text { actually have three, but two of them are certified. And then I } \\
\text { have bilingual support on the clinical side. There's three } \\
\text { individuals in the back, on the clinical side, that are bilingual } \\
\text { and certified. } \\
\text { have more Spanish-speaking or bilingual staff and providers } \\
\text { than in Pendleton. } \\
\text { making sure we have staff that supports them, with the } \\
\text { that are more rare. But we're seeing a little bit more in our } \\
\text { area, like Somalian and Arabic. }\end{array}$ & $\begin{array}{l}\text { In some clinics, Spanish-speaking providers } \\
\text { and care staff are a necessity. } \\
\text { In areas with large populations of primarily } \\
\text { Spanish-speakers, bilingual staff allow } \\
\text { clinics to feel confident in their abilities to } \\
\text { help patients. } \\
\text { Bilingualism is a valuable skill and is one that } \\
\text { is not always easy to come by. } \\
\text { Being able to communicate directly with } \\
\text { patients is preferred; language concordance } \\
\text { allows for this. } \\
\text { Theme: Importance of onsite communication }\end{array}$ \\
\hline
\end{tabular}




\begin{tabular}{|c|c|c|}
\hline Categories & In Vivo Quotes & Concluding Discussion \\
\hline Phone & $\begin{array}{l}\text { We have one receptionist that speaks Spanish. And usually, if } \\
\text { there seems to be a language barrier, our receptionists will } \\
\text { transfer people to her. } \\
\text { Well, one of our receptionists is not fluent, but conversant } \\
\text { enough, I guess you would say, to - and also, I am } \\
\text { conversant enough to be able to say, "let me connect you } \\
\text { with, Linguava" - and they have it posted right in front of } \\
\text { them - so they would say, "hold on, let me connect you } \\
\text { through that," and then we would get the translator on. } \\
\text { pull the provider if she was available, but sometimes, not } \\
\text { always. } \\
\text { The folks in town generally have their children call, because } \\
\text { their children sometimes speak English pretty well. } \\
\text { But I think they mostly have their children call in and make } \\
\text { appointments, though. } \\
\text { Most patients, when they call in, they'll have their child or } \\
\text { somebody that speaks English call in for them and say they } \\
\text { need to make an appointment. } \\
\text { If there has been, it's not been, you know, with them being } \\
\text { bilingual, it's been, you know, a Somalian or an Arabic family, } \\
\text { and then we've gotta get the interpreter line on there. }\end{array}$ & $\begin{array}{l}\text { Patients will rely on family (often younger } \\
\text { generation children) to set up appointments. } \\
\text { Persons that speak some Spanish (but not } \\
\text { fluently) are good assets for front office } \\
\text { visits. And can switch to interpreter services } \\
\text { if necessary. } \\
\text { Receptionists can rely on other staff that } \\
\text { speaks Spanish to assist with phone calls. } \\
\text { Theme: Phone calls do not pose a major barrier } \\
\text { to communication }\end{array}$ \\
\hline $\begin{array}{l}\text { Ad hoc } \\
\text { interpreters }\end{array}$ & $\begin{array}{l}\text { We can use family members as far as just, getting } \\
\text { demographic information, maybe history and things like that, } \\
\text { but when it comes time to talk diagnosis and treatment, we } \\
\text { try to use the translational services. } \\
\text { We try not to do that in a room, because we are not supposed } \\
\text { to use family as interpreters in the room. } \\
\text { they don't know medical, so, it probably wouldn't be } \\
\text { translated the way it should be. } \\
\text { And so, we have to tell patients to bring somebody with them. } \\
\text { And that's kind of hard to do because most of time it's a } \\
\text { child. } \\
\text { Most of them know to bring somebody that's over } 18 \text { that can } \\
\text { interpret for them, because we can't really have a child that's }\end{array}$ & $\begin{array}{l}\text { In most clinics, ad hoc interpreters are used } \\
\text { only in initial check-in of appointments. } \\
\text { Clinic staff understand the dangers of using } \\
\text { ad hoc interpreters. } \\
\text { Some clinics do rely on ad hoc interpreters as } \\
\text { a normal practice. } \\
\text { Policy of legality of ad hoc interpretation is } \\
\text { not known in some cases. }\end{array}$ \\
\hline
\end{tabular}




\begin{tabular}{|c|c|c|}
\hline Categories & In Vivo Quotes & Concluding Discussion \\
\hline & $\begin{array}{l}\text { under } 18 \text { coming in. That's not really focusing on what their } \\
\text { parent's need is, but that's pretty much how they do that } \\
\text { here. } \\
\text { you have to make sure that, whoever they're bringing in here, } \\
\text { understands how HIPPA laws and everything and protection } \\
\text { for the patient }\end{array}$ & \\
\hline $\begin{array}{l}\text { Benefits to } \\
\text { 3rd party } \\
\text { interpreter } \\
\text { agencies }\end{array}$ & $\begin{array}{l}\text { Thank goodness for Passports to Languages, or else we } \\
\text { would have a very hard time communicating with them. } \\
\text { we looked at a bunch of different services and, the thing that } \\
\text { we liked about it was that you could use it } 24 \text { hours a day, } \\
\text { but you could also — there were so many languages } \\
\text { available. } \\
\text { it's been used very seldom - but so far, it's been really } \\
\text { good. } \\
\text { we've just continued to use the Passport to Languages. And } \\
\text { I think the more that we've used it, the more comfortable our } \\
\text { providers and clinical staff have gotten with it. } \\
\text { We're so used to this. }\end{array}$ & $\begin{array}{l}\text { Clinics feel supported by interpretation } \\
\text { agencies. } \\
\text { Language services are a useful tool. It is easy } \\
\text { to use and effective. } \\
\text { With more practice using remote } \\
\text { interpretation, providers and staff become } \\
\text { accustomed to its functionality. } \\
\text { Theme: Interpreter agencies are a valuable } \\
\text { asset }\end{array}$ \\
\hline $\begin{array}{l}\text { Interpreters: } \\
\text { onsite vs. } \\
\text { remote }\end{array}$ & $\begin{array}{l}\text { It is better in-person, they prefer that } \\
\text { They feel like easier to have the person there doing the } \\
\text { translation. Than to actually not know who is on the other } \\
\text { end, it's a little less comforting. } \\
\text { they also prefer when the person is there in-person. } \\
\text { And it would be nice to have Spanish-speaking interpreters as } \\
\text { well, but we generally don't have them } \\
\text { We just want to make sure we're giving the best care possible } \\
\text { and that they understand. And so, if we could get an in- } \\
\text { person interpreter, that would be, ideal. } \\
\text { And we did have a company that was sending out sign } \\
\text { language folks to help us with the sign. } \\
\text { I think, for speed, it is usually easier to have an in-person visit. }\end{array}$ & $\begin{array}{l}\text { Clinic staff prefer in-person interpreters over } \\
\text { remote. } \\
\text { In-person interpreters are easier to work, } \\
\text { more time efficient, and it is helpful to be } \\
\text { able to double-check that everything was } \\
\text { understood/heard properly. } \\
\text { Onsite interpreters are not commonly used. } \\
\text { This is because they are unavailable. } \\
\text { For ASL, in-person interpretation is } \\
\text { necessary (when video is unavailable). } \\
\text { However, they are not always available. } \\
\text { Theme: Preference for onsite interpretation, } \\
\text { despite limited resources }\end{array}$ \\
\hline
\end{tabular}




\begin{tabular}{|c|c|c|}
\hline Categories & $\begin{array}{l}\text { In Vivo Quotes } \\
\text { That would enhance the service for the patient a bit, yeah. It } \\
\text { could. Although I don't think it's the biggest need, but that } \\
\text { could be helpful. } \\
\text { because then you have them right there. You don't have the } \\
\text { issue of, 'did they understand me correctly over the phone? } \\
\text { Did everything get interpreted the right way.?' Whereas } \\
\text { face-to-face, it's a little bit easier. } \\
\text { So, it's just not ideal, of course, you know, but it works. } \\
\text { We did have one family that brought a child that the child was } \\
\text { not deaf. And so, the child, we were able to communicate } \\
\text { with pen and paper. With them, writing down the questions } \\
\text { and stuff, because that is so one thing: American Sign } \\
\text { Language, you can't really do over the phone. } \\
\text { in the more urban areas, there's probably an overabundance } \\
\text { of it - or, at least, maybe, more opportunity for face-to- } \\
\text { face. }\end{array}$ & Concluding Discussion \\
\hline $\begin{array}{l}\text { Interpreters: } \\
\text { Over-the- } \\
\text { phone } \\
\text { interpreting } \\
\text { vs. video } \\
\text { remote } \\
\text { interpreting }\end{array}$ & $\begin{array}{l}\text { the phone service is OK, the video is kind of, preferred a lot } \\
\text { of times } \\
\text { everybody in the room can talk and see each other. } \\
\text { on the other end it's a little less comforting. } \\
\text { handing over the phone or putting it on speaker. It's kind of } \\
\text { hard when you're on speaker, because you're breaking } \\
\text { HIPPA, and you're breaking confidentiality. So, you have to } \\
\text { be careful when you do that online, over-the-phone, on } \\
\text { speaker. } \\
\text { It's awkward, but it does serve. }\end{array}$ & $\begin{array}{l}\text { Staff prefer to use VRI over OPI. } \\
\text { VRI feels more personable, is less awkward, } \\
\text { and all parties can more easily speak } \\
\text { (including family in the room). } \\
\text { Most clinics do not have access to video } \\
\text { technologies and rely on phone } \\
\text { interpretation. } \\
\text { Theme: Preference for video interpretation }\end{array}$ \\
\hline $\begin{array}{l}\text { Challenges: } \\
\text { insufficient } \\
\text { resources }\end{array}$ & $\begin{array}{l}\text { So, it makes it really hard when we have a new patient that } \\
\text { needs to get in to see a doctor and they don't speak English. } \\
\text { You can't just cancel the appointment and say "oh, come } \\
\text { back tomorrow, we'll have that person come in and help, "it } \\
\text { doesn't work that way. } \\
\text { And so, without me not being able to let her know that, she } \\
\text { would have ended up, they would have ended up having to } \\
\text { reschedule and have her come back. }\end{array}$ & $\begin{array}{l}\text { Bilingual staff (especially Spanish speaking) } \\
\text { is perceived as a missing resource in clinics. } \\
\text { Some clinics that lack bilingual providers will } \\
\text { rely on uncertified bilingual staff for } \\
\text { interpretation. }\end{array}$ \\
\hline
\end{tabular}




\begin{tabular}{|c|c|c|}
\hline Categories & In Vivo Quotes & Concluding Discussion \\
\hline & $\begin{array}{l}\text { So, it's just a matter of, the communication up front, or when } \\
\text { they're calling to make an appointment with a provider. If } \\
\text { they don't speak English, I think it's very important that they } \\
\text { say, "if you don't speak English, then we need you to bring } \\
\text { an interpreter, or we can call one for you and have them } \\
\text { ready. " I think that would be the best thing to do, it would } \\
\text { save time. } \\
\text { none of our providers speak Spanish up there. } \\
\text { We don't really have the face-to-face availability } \\
\text { So, that's one of the things that lacks here, is that, we don't } \\
\text { have a lot of our staff, to be able to be available for some of } \\
\text { the patients. } \\
\text { we're very low on staff to be able to have anybody to } \\
\text { translate. So, a lot of times we have one person who works } \\
\text { in our lab who speaks Spanish. Sometimes they'll call him } \\
\text { and ask him to go and translate. But, it's very hard for them } \\
\text { to do that because he can't leave the lab area all the time. }\end{array}$ & $\begin{array}{l}\text { Better communication is necessary to make } \\
\text { sure that staff is available to interpret for } \\
\text { providers and care staff. } \\
\text { Bilingual staff lacks certification, but is still } \\
\text { relied on for interpretation. } \\
\text { Theme: Lacking bilingual/certified staff and } \\
\text { in-person interpreters }\end{array}$ \\
\hline $\begin{array}{l}\text { Challenges: } \\
\text { CCOs }\end{array}$ & $\begin{array}{l}\text { we feel like they should be providing us with the sign } \\
\text { person. And they are few and far between. We struggle every } \\
\text { time we need a sign language person to come and help us } \\
\text { with this patient's visit } \\
\text { They're supposed to provide us with sign language. I think we } \\
\text { have actually found them ourselves and then I think Trillium } \\
\text { reimburses them. But we've had some real difficulties with } \\
\text { that. } \\
\text { Yeah, we call their line and we give them their medical ID } \\
\text { number and then they bill them versus us directly. There are } \\
\text { some occasions when we get billed directly because they } \\
\text { might not have been active at that given point in time. } \\
\text { we're part of, or, the Cco here, the Columbia Pacific Cco, also } \\
\text { does offer in-person interpreters for their patients. } \\
\text { there's gonna be some Ccos support more rural type areas, } \\
\text { where they may not have the resources available to hire } \\
\text { and get interpreters like that. }\end{array}$ & $\begin{array}{l}\text { Some CCOs are challenging to work with, } \\
\text { with regards to reimbursing clinics for costs } \\
\text { of interpreters. } \\
\text { Some CCOs do provide language services to } \\
\text { their clinics. But others only reimburse for } \\
\text { costs of interpreter expenses. Clinics feel } \\
\text { CCOs should provide those services. } \\
\text { There are irregularities with regards to } \\
\text { services that CCOs provide. State regulation } \\
\text { would insure CCOs offer same services } \\
\text { across the state. } \\
\text { Theme: Irregularities in CCO language } \\
\text { resources/reimbursements }\end{array}$ \\
\hline
\end{tabular}




\begin{tabular}{|c|c|c|}
\hline Categories & In Vivo Quotes & Concluding Discussion \\
\hline & $\begin{array}{l}\text { And in those instances, I have to use the language line, } \\
\text { through the Oregon Health Plan. } \\
\text { the cco has been able to use services that are provided to } \\
\text { the members. }\end{array}$ & \\
\hline $\begin{array}{l}\text { Challenges: } \\
\text { certification }\end{array}$ & $\begin{array}{l}\text { It would be nice if they would just test her. Speak to her and } \\
\text { see if she has it, without making her go through all that. } \\
\text { she's fluent. And, her family speaks Spanish. And her mother } \\
\text { speaks nothing but Spanish. And so, she's fluent in it. But } \\
\text { the state required her to be certified. And in order to do that, } \\
\text { it was a pretty large expense on the clinic's part. And she } \\
\text { was insulted because she is Spanish and fluent in Spanish. } \\
\text { And for her to have to go through a tedious certification } \\
\text { process, she did not like it. } \\
\text { And an expense to our clinic, which we're very small. } \\
\text { Actually, I got a scholarship to go through the Coastal Health } \\
\text { Care Interpreter Online Training. So, I'm going to be doing } \\
\text { that. }\end{array}$ & $\begin{array}{l}\text { Certifying bilingual staff is an obstacle that } \\
\text { some feel makes it more challenging for their } \\
\text { staff to treat patients. } \\
\text { Certification processes are expensive, and } \\
\text { can especially be difficult for smaller clinics. } \\
\text { Some staff have been awarded scholarships } \\
\text { for courses. Additional scholarships would } \\
\text { allow more staff to meet the requirements of } \\
\text { the state. } \\
\text { Theme: Certification is expensive and } \\
\text { challenging to obtain }\end{array}$ \\
\hline $\begin{array}{l}\text { Community: } \\
\text { working } \\
\text { together } \\
\text { with other } \\
\text { clinics in } \\
\text { the area }\end{array}$ & $\begin{array}{l}\text { So, the same providers, that staff the clinic in Fossil, travel } \\
\text { two days a week to Spray and to Mitchell. } \\
\text { They also interpret for other hospital departments. But they } \\
\text { are employed in our clinic, they're here all the time. } \\
\text { So, I've had to translate and assist the doctors in providing, } \\
\text { health care services to them. So that's kind of how we get } \\
\text { some of the patients that come here, especially in it's in that } \\
\text { department or, any other department that - maybe those } \\
\text { other clinics may not have. } \\
\text { most of our patients, Hispanic patients, they usually will go } \\
\text { over to Waterfall, and then they get referred here for } \\
\text { specialists, if they have to see a certain specialist. They will } \\
\text { make a note on the referral, saying "Spanish person, Spanish } \\
\text { speaking, needs assistance, needs interpreter." } \\
\text { I'm not sure that any of the other primary care clinics in } \\
\text { Pendleton have interpreters or bilingual staff. }\end{array}$ & $\begin{array}{l}\text { Community partnerships form a network of } \\
\text { support, these are crucial when resources } \\
\text { are limited. } \\
\text { In small communities, limited staff move } \\
\text { around to different clinics to serve patients. } \\
\text { Having any bilingual staff/providers means } \\
\text { patients in all clinics can be seen. } \\
\text { In some communities, specific clinics have } \\
\text { bilingual staff/providers. Those clinics seems } \\
\text { to serve more Spanish-speaking patients. } \\
\text { When LEP patients are referred to a } \\
\text { specialist, providers will make sure to make } \\
\text { a note for language services on referral. } \\
\text { Bilingualstaff will move between departments } \\
\text { or go with patients to other clinics/hospitals } \\
\text { to provide language support. }\end{array}$ \\
\hline
\end{tabular}




\begin{tabular}{|c|c|c|}
\hline Categories & In Vivo Quotes & Concluding Discussion \\
\hline & $\begin{array}{l}\text { I only know this personally because I've actually had to leave } \\
\text { my work office and go with the patient and take them to the } \\
\text { hospital and translate for them }\end{array}$ & $\begin{array}{l}\text { Theme: Rural communities collaborate } \\
\text { limited resources to meet needs }\end{array}$ \\
\hline $\begin{array}{l}\text { Perception: } \\
\text { patients } \\
\text { prefer } \\
\text { bilingual } \\
\text { staff }\end{array}$ & $\begin{array}{l}\text { it gives them an alternative place to go and still be able to } \\
\text { have translation services and bilingual staff. } \\
\text { a lot of patients go to Waterfall Clinic. There's a little bit more, } \\
\text { I think there might be a little bit more staff there that may be } \\
\text { able to assist with a Spanish-speaking person versus what } \\
\text { we have here. } \\
\text { A lot of coming from Hermiston and Milton- } \\
\text { Freewater, because we have somebody that they can talk to, } \\
\text { because we have Spanish-speaking staff. }\end{array}$ & $\begin{array}{l}\text { Clinic staff perceive that LEP patients might } \\
\text { prefer to work with bilingual staff versus } \\
\text { interpreters. } \\
\text { Staff perceives higher LEP patient volume at } \\
\text { clinics with more onsite resources. } \\
\text { LEP patients will travel to be seen by a } \\
\text { Spanish-speaking provider. } \\
\text { Theme: LEP patients prefer onsite language } \\
\text { concordance }\end{array}$ \\
\hline $\begin{array}{l}\text { Community: } \\
\text { big hospital } \\
\text { support }\end{array}$ & $\begin{array}{l}\text { And an expense to our clinic, which we're very small. } \\
\text { I don't know if they have the same issues at the hospital. They } \\
\text { must! I would think. They may have Spanish-speaking folks } \\
\text { over there. } \\
\text { I think there are a couple other folks - at least one for sure } \\
\text { that I know of - that are working on it in the hospital. And } \\
\text { they'll have other resources there, and won't call ours to } \\
\text { help with that. } \\
\text { we have a standard protocol. We will get in touch with our } \\
\text { interpreter service: OHSU interpreter services. And, get them } \\
\text { on the line with the patient. And then there would be a three- } \\
\text { way call. } \\
\text { Yeah, it goes through the hospital. You know, we, of course, } \\
\text { pay our quote on quote "taxes" to them, and they do help to } \\
\text { support those kinds of centralized services. } \\
\text { I'm sure there are other clinics and whatnot that struggle with } \\
\text { it more than we do. }\end{array}$ & $\begin{array}{l}\text { Small clinics face harder challenges with } \\
\text { financial burden of interpretation and } \\
\text { certification of bilingual employees. } \\
\text { Large hospital organizations can financially } \\
\text { assist clinics with language services. Or, } \\
\text { some larger hospitals will provide services to } \\
\text { their clinics. } \\
\text { Theme: Small health centers are } \\
\text { significantly impacted by costs associated } \\
\text { with language resources }\end{array}$ \\
\hline
\end{tabular}




\begin{tabular}{|c|c|c|}
\hline Categories & In Vivo Quotes & Concluding Discussion \\
\hline $\begin{array}{l}\text { Perception: } \\
\text { LEP } \\
\text { population } \\
\text { growth }\end{array}$ & $\begin{array}{l}\text { I think, with the increasing numbers, I think is probably } \\
\text { necessary to have more staff who can communicate in } \\
\text { Spanish } \\
\text { Yes, I think our Spanish-speaking patients have increased } \\
\text { some } \\
\text { we had zero Spanish-speaking, before I came. And I came } \\
\text { about a year and a half ago and then sought that audience, } \\
\text { and now we have } 25 \text { households } \\
\text { But we're seeing a little bit more in our area, like Somalian } \\
\text { and Arabic. } \\
\text { in the Somalian and the Arabic population. I feel like, when } \\
\text { we first started, you know, we had like one or two and now I } \\
\text { feel like we have kind of more like a handful of families. }\end{array}$ & $\begin{array}{l}\text { More patients with LEP are being seen by } \\
\text { clinics. } \\
\text { Clinic staff believes that LEP population } \\
\text { growth means an increased need for certified } \\
\text { bilingual staff. } \\
\text { Having more trained interpreters for in- } \\
\text { person visits would help with increasing LEP } \\
\text { populations. } \\
\text { Theme: LEP populations are growing }\end{array}$ \\
\hline
\end{tabular}

